DOI: $10.15393 /$ j10.art.2019.4141

УДК $930.25+17.81 .31$

М. В. Заваркина

Петрозаводский государственный университет

(Петрозаводск, Российская Федерация)

dostoyevsky@mail.ru

\title{
Редакционные записи в составе записных книжек Ф. М. Достоевского 1860-1865 гг.
}

\begin{abstract}
Аннотация. В статье анализируются фрагменты из записных книжек Ф. М. Достоевского (ОР РГБ. Ф. 93.I.2.6, 93.I.2.7, 93.I.2.8), которые писатель вел в 1860-1865 гг. параллельно с изданием журналов «Время» и «Эпоха». Некоторые записи до сих пор не расшифрованы или расшифрованы не точно, к другим отсутствуют комментарии. В статье предпринята попытка прочтения отдельных записей с учетом характерных особенностей почерка писателя, а также предложены комментарии, дополняющие комментарии к первой публикации книжек в 83 томе «Литературного наследства» (1971) и позднее в 20 томе Полного собрания сочинений Ф. М. Достоевского в 30-ти томах (1980). Выявление и изучение данных записей в составе записных книжек и тетрадей Достоевского позволит более подробно осветить напряженную жизнь писателя в период редакторской деятельности в журналах «Время» и «Эпоха», а также понять характер его работы как писателя и журналиста. Тема статьи требует дальнейшей разработки и носит дискуссионный характер. Ключевые слова: Ф. М. Достоевский, «Время», «Эпоха», рукопись, атрибуция, записные книжки и тетради
\end{abstract}

Об авторе: Заваркина Марина Владимировна - кандидат филологических наук, специалист WEB-лаборатории Института филологии, Петрозаводский государственный университет (пр. Ленина, 33, г. Петрозаводск, Республика Карелия, Российская Федерация, 185910)

Дата поступления: 15.07 .2019

Дата публикации: 14.09.2019

Для цитирования: Заваркина М. В. Редакционные записи в составе записных книжек Ф. М. Достоевского 1860-1865 гг. // Неизвестный Достоевский. - 2019. - № 3. - С. 67-95.

DOI: $10.15393 /$ j10.art.2019.4141

3 аписные книжки и тетради - важная часть творческого процесса Ф. М. Достоевского. В период с 1860 по 1865 г. писатель ведет параллельно несколько записных книжек и тетрадей, в которые (кроме собственно литературных и публицистических замыслов и набросков) вносит записи, помогающие понять характер его редакторской работы в журналах «Время» и «Эпоха».

В фондах ОР РГБ (ф. 93.I.2.6, 93.I.2.7 и 93.I.2.8) хранятся три записные книжки Достоевского 1860-1865 гг. Возможно, была еще одна книжка или тетрадь, которую Достоевский вел в этот период. Известно, что осенью 1863 г. в Москве писатель потерял сак с вещами и документами‥ Разработок собственно литературных произведений в данных книжках немного ${ }^{2}$, главное место в них занимают публицистические замыслы, наброски полемических статей, разработки «Объявлений» о подписке на журналы «Время» и «Эпоха», финансовые расчеты по редакторской и издательской деятельности.

(C) М. В. Заваркина, 2019 
В основе этих первых книжек, по мнению исследователей, лежит тенденция к синтезу, т. е. «принципиальное нерасчленение черн<овых > записей к произв<едениям>, выписок и записей публиц<истического $>$ характера, набросков критич<еских> статей» [Достоевский, Словарь: 379]. Параллельно с книжками, в 1864 г., Достоевский заводит тетради бо́льшего формата, в двух из которых, хранящихся в фондах РГАЛИ (ф. 212.1.3 и 212.1.4), продолжается своеобразный «отчет» о ведении дел в редакции «Эпохи». Рядом с черновыми материалами к «Крокодилу» и роману «Преступление и Наказание» даны перечни статей по номерам, листажи статей, гонорарные списки, что позволило исследователям сравнить эти первые тетради с «Приходно-расходными журналами по изданию журналов “Время" и “Эпоха”". Особое значение имеют перечни писем, которые Достоевский планировал написать: они дают «сведения о круге знакомых Достоевского, а порою и позволяют значительно расширить список не дошедших до нас его писем или подсказать источники, к которым следует обратиться в поисках подобных писем» (Д30; 27: 355). Записи показывают, какой напряженной была жизнь писателя в это время, насколько огромным был «масштаб его редакторской работы»: Достоевский «лично и вместе с братом редактировал ежемесячно по 25-30 авт. л.» [Захаров, 2013а: 17].

Некоторые записи из этих книжек и тетрадей до сих пор не расшифрованы или расшифрованы не точно, к некоторым отсутствуют комментарии. «Первая» записная книжка (ОР РГБ. Ф. 93.I.2.6, далее - 3К $)$, датируемая 1860-1862 гг. ${ }^{3}$, содержит в основном замыслы будущих критических статей Достоевского, бо́льшая половина из которых так и не была воплощена писателем (например, статья о Шекспире, «Ряд статей о судах», «Аномалии Европы и России», «Что значит Рим для Папы», «Гоголь и Островский» ${ }^{4}$ и т. д.). Некоторые замыслы были переработаны в другие, например, в «Ряд статей о русской литературе» (Время. 1861. Январь) или в статью «Г. -бов и вопрос об искусстве» (Время. 1861. Февраль). Задумывал Достоевский и несколько критических "разборов» для специального отдела «Критика» в журнале «Время» ${ }^{5}$ (см. запись на с. $\left.1043 K_{1}\right)$ :

«непремпнно разборы.

- Читальникъ.

- По поводу одной рецензіи

- Aвторитеты (и Чернышевск<ій>)

- Кузвма Прутковъ.

- Поэтики: Всеволодъ Крестовск<ій>, Д. Минаевъ, Николай Курочкинъ и проч.

Кохановская

Гончаровъ». 
Как видим, разбор «Читальника» Н. Ф. Щербины находится на первом месте. Имеется в виду статья Щербины «Опыт книги для народа», которая вышла во втором номере журнала «Отечественные Записки» за 1861 г. В журнале «Время» об этом проекте писал П. А. Кусков в заметке «Вместо фельетона» (Время. 1861. Май; без подписи). Имя автора установлено В. А. Тунимановым на основании прямой отсылки в тексте статьи к предыдущему фельетону П. А. Кускова «Некоторые размышления по поводу некоторых вопросов» (см.: Д30; 19: 350). О. фон Шульц приписывал заметку Ф. М. Достоевскому на основании того, что речь в ней идет о «народной хрестоматии», ведь рассуждения о книге для народного чтения были развиты Достоевским в августовском номере «Эпохи». Атрибуцию Шульца оспорил Б. В. Томашевский, указав на тот факт, что статья «Вместо фельетона» содержит примечание редакции, а в анонимных статьях Достоевского подобных примечаний не наблюдается (см.: [Достоевский, 1930: 610]): «В скором времени мы надеемся поместить обстоятельный разбор статьи г-на Щербины» (Д30; 19: 213; ср.: [Нечаева, 1975: 237, 263]6). Это обещание Достоевский сдержал: посвятил разбору «Читальника» вторую статью «Книжность и грамотность» (Время. 1861. Август). Однако уже в первой статье «Книжность и грамотность» (Время. 1861. Июль) Достоевский освещал проблемы народа и чтения для народа (подробнее см.: [Туниманов: 445-467]). Впервые статья «Вместо фельетона» включена в собрание сочинений в издании: «Полное собрание сочинений Ф. М. Достоевского в авторской орфографии и пунктуации» (Ө. Д., V: 483-497). По мнению комментаторов издания, «в фельетоне П. А. Кускова имеются развернутые вставки Достоевского со слов: “Во второй книжкъ <...> до слов: “Зачъмъ же навязывать?”, а также со слов: “Нуженъ сильный самостоятельный талантъ...” до слов: “...отношеніе донъ-Кихота къ настоящему рыцарству”» (Ө. Д., V: 852; см. также: [Захаров, 2004: 705]).

В $3 K_{1}$ мы нашли еще одну запись, касающуюся этого проекта, она расположена внизу с. 4, в направлении, обратном основному тексту, и не была прочитана в первых публикациях. Запись сделана карандашом, густо зачеркнута, но при обращении непосредственно к оригиналу, а также (если говорить о фотокопии) при усилении контрастности рисунка отдельные слова прочитать можно, так как угадываются характерные для почерка писателя буквы и буквенные сочетания (см. Илл. 1). 

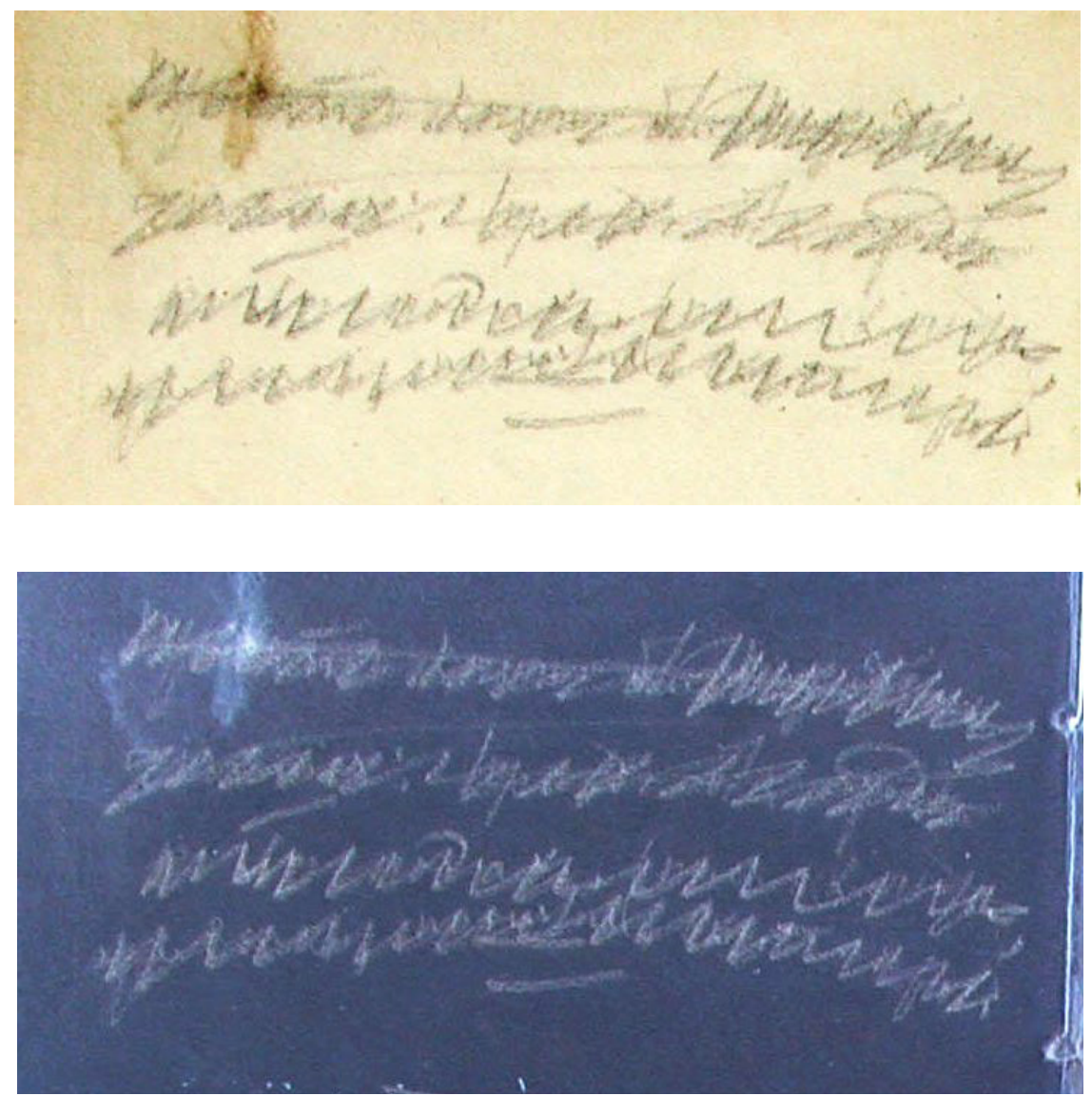

Илл. 1. Фрагменты стр. $43 K_{1}$

Передаем подстрочную расшифровку записиㄱ:

«Проэкть книги для Нар<однаго> Чт<енія>,

y насъ: проэк<тъ> для народа

о Господахъ (m. е. о <нрзб.>,

унасъ $\{$ понятн. $<$ <нрзб.>».

В слове «Проэктъ» узнаваемо традиционное написание прописной буквы «П» и строчных букв «т» и «ъ» на конце слова (см. Илл. 2). Один из вариантов написания буквы «т» в почерке Достоевского - с тремя вертикальными штрихами, соединенными дугообразным элементом с надстрочным штрихом или без него (подробнее см.: [Тарасова: 40-59]). 

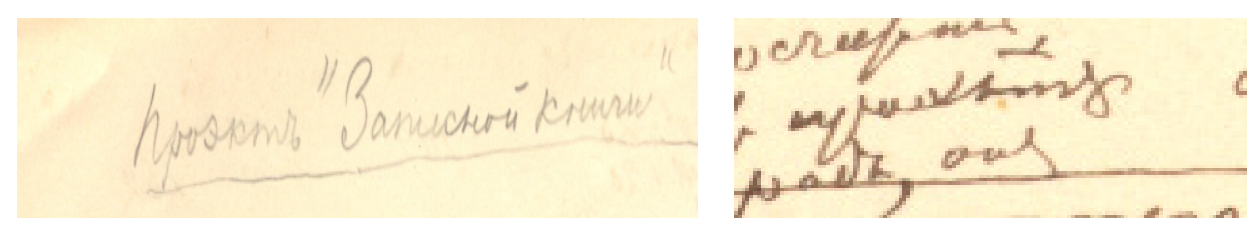

Илл. 2. Фрагмент с. 34 и 125 записной тетради 1864-1865 гг.

(РГАЛИ. Ф. 212.1.3)

Во втором примере (с. 125, илл. 2) видим слияние букв «К» и «т», как и в нашей записи. Учитывая, что набросок в $3 K_{1}$ сделан карандашом, наскоро, с сокращениями, некоторые буквы получились немного сжатыми. Также на с. 34 (см. Илл. 2) находим вариант написания слова «книги», который читается и в нашей записи.

Предлог «для» написан в характерной для Достоевского манере: чаще всего букву «д» он пишет с верхним выносным элементом с завитком, в букве «Л» находим традиционный верхний выносной штрих, буква «я» почти не видна, так как на нее накладывается верхний штрих от прописной буквы «Н» следующего слова. Сравним абсолютно идентичное написание данного предлога в словосочетании «не для худого» в записной тетради 1864-1865 гг. (см. Илл. 3).
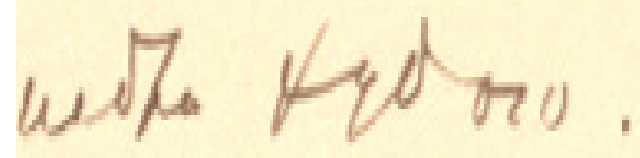

Илл. 3. Фрагмент с. 117 записной тетради 1864-1865 гг.

(РГАЛИ. Ф. 212.1.3)

При прочтении первых трех слов «Проэктъ книги для...» автоматически вспоминается словосочетание «Народного Чтения», так как речь об этом проекте в данной книжке уже велась. Особенно узнаваема прописная буква «Ч» с четким верхним изгибом, не позволяющим спутать ее с другими буквами, например, с заглавной «Г». Сравни написание прописной буквы «Ч» в словах «Читальникъ», «Черныпевск<ій>» на с. 104 3К (Илл. 4): 
72

М. В. Заваркина

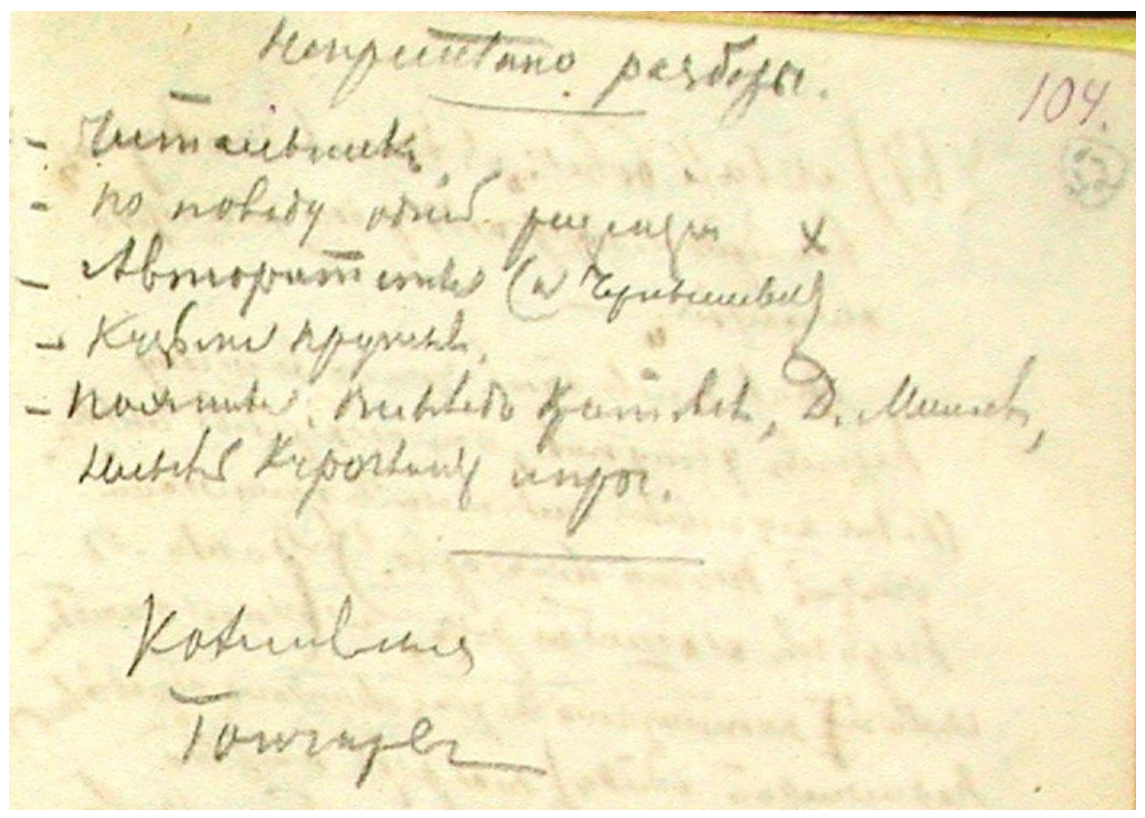

Илл. 4. Фрагмент с. $1043 K_{1}$

Букву «у» (сочетание «у насъ» в начале второй и четвертой строк (см. Илл. 1)) Достоевский пишет одинаково: нижняя часть нередко остается в пределах строки, а сама буква схожа с вариантом написанием строчной «т». Сравни, например, в той же $3 K_{1}$ сочетание «у насъ» в предложении «Куда ужъ сложныхъ у насъ самьхъ...» (см. Илл. 5).
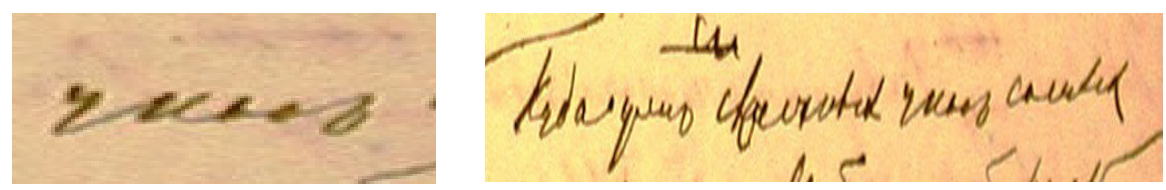

Илл. 5. Фрагмент с. $1023 K_{1}$

Далее на Илл. 1 четко видно двоеточие и незаконченное слово «проэк<mъ>». Предлог «для» написан точно так же, как и в предыдущей строке. Поскольку данный проект разрабатывался для народа, а по внешнему облику в последнем слове второй строки угадываются буквы «р» и «д», то мы предположили, что написано именно слово «народа». В сочетании «о Господахъ» наблюдаем прописную букву «Г», которая в почерке Достоевского практически не имеет вариантов: горизонтальный штрих с завитком или без него накладывается на вертикальный, как в данном примере. Также в рисунке слова проглядывается строчная буква «д», которая чаще всего пишется 
с верхним выносным элементом и может иметь развернутый завиток, как в нашем случае (подробнее см.: [Тарасова: 40-59]).

Известно, что Достоевский выступал против поучительного «господского» тона в произведениях для народа, критиковал сам отбор этих произведений для народного чтения, которые были глубоко чужды народу и его интересам. Во второй статье «Книжность и грамотность», после критического разбора статьи Н. Щербины, Достоевский предлагает «свой» проект и делает вывод: «Но господскаго-то обученія онъ <народ> не любитъ; не любитъ, чтобъ глядъли-то на него свысока, чтобъ въ опеку его брали даже и тогда, когда онъ полное право имъетъ самъ по своей воль и охоть поступать» (Ө. Д.; IV: 540).

Далее в рукописи четко видна открывающая скобка и сокращение «m. e.», на которое плотным слоем накладывается дуга от зачеркивающего элемента, расшифровка последних слов третьей и четвертой строк остается под вопросом. Однозначно прочитывается вписанное над двумя короткими чертами сокращенное слово «понятн.», оно не зачеркнуто, а потому легко расшифровывается при обращении к оригиналу рукописи. Что имелось в виду, можно только догадываться, исходя из контекста. Возможно, речь идет о «понятной» народу книге для чтения.

На с. $193 K_{1}$ сохранилась угасшая запись карандашом (см. Илл. 6), которая при первой публикации книжки в 1971 г. в 83 томе «Литературного наследства» ${ }^{8}$ была прочитана следующим образом: «На свете ничего не начинается и ничего не оканчивается. / Чудо воскр<есения> нам сделано нарочно для того, чтоб оно впоследствии соблазняло, но верить должно, так как этот соблазн (перестанешь верить) и будет мерою веры» [ЛН, т. 83: 128]. Точно так же запись воспроизведена в 20 томе Полного собрания сочинений Ф. М. Достоевского в 30 т. (см.: Д30; 20: 152).

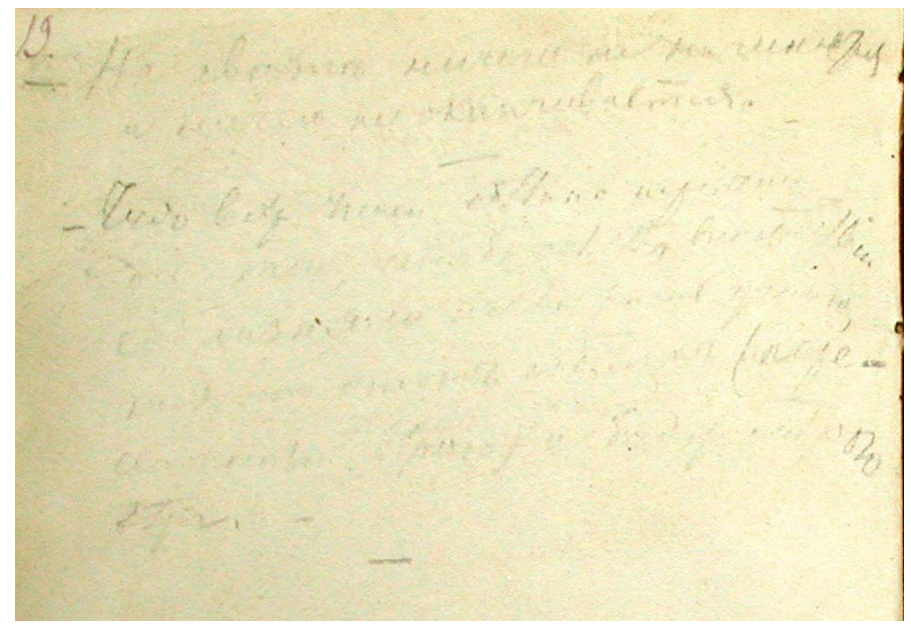

Илл. 6. С. $193 K_{1}$ 
Вся запись, навеянная, видимо, приближающейся Пасхой, при обращении к оригиналу, de visu, читается так (передаем строфику для удобства, разночтения выделены полужирным начертанием) ${ }^{9}$ :

«- На свптп ничего не начинается

и ничего не оканчивается.

- Чудо въ Хр <истіанскомб > Уиеніи сдюлано нарочно

для того, чтобъ человпка впосльдствіи

соблазняло не вприть ученію,

такъ какъ этоть соблазнь (пере-

станешь вторить) и будетг мтроюю

вторы. -

».

Запись перекликается с более поздними рассуждениями героя поэмы Ивана Карамазова «Великий инквизитор»: «...чуть лишь человек отвергнет чудо, то тотчас отвергнет и Бога, ибо человек ищет не столько Бога, сколько чудес» (Д30; 14: 233). Мотив чуда, которое используется для соблазна людей, проходит через все творчество Достоевского. Писатель обращается к теме трех «дьяволовых искушений» (чудом, тайной и авторитетом) уже в период работы над романами «Преступление и Наказание» и «Идиот». Затем эта тема вновь возникает в «Подростке», и, наконец, находит полное воплощение в романе «Братья Карамазовы» (см.: Д30; 15: 409).

На с. 47 3К видим список имен и фамилий тех людей, которым Достоевский должен был написать или у кого обещал быть лично. Карандашная запись полустерта и прочитывается с трудом (см. Илл. 7).

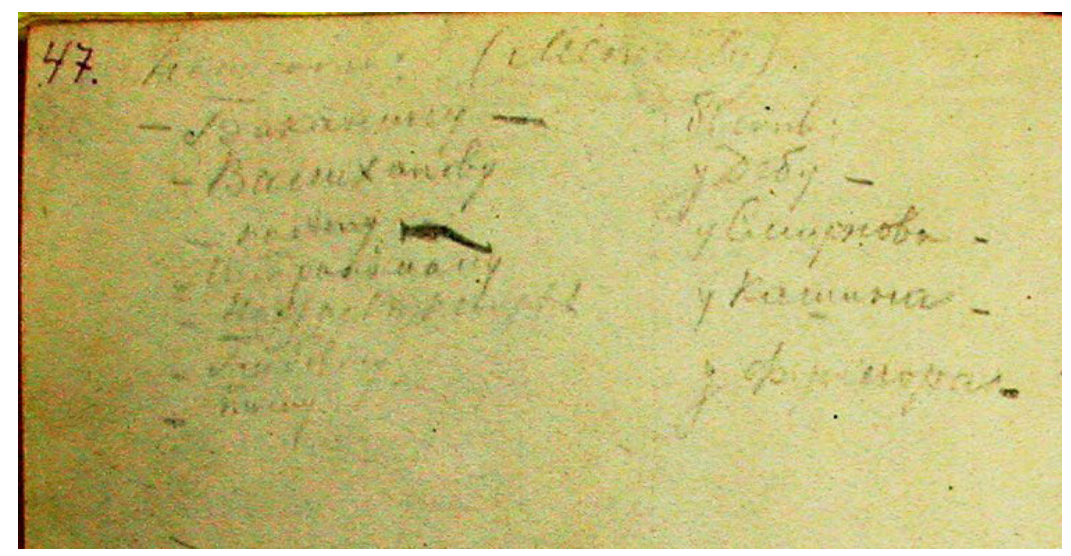

Илл. 7. С. $473 K_{1}$ 
«Hanucamb: (Memento)

- Баканину

$$
\begin{aligned}
& \text { быть: } \\
& \text { у Дебу- } \\
& \text { у Смирнова- } \\
& \text { у Камина - } \\
& \text { у Фермора -». }
\end{aligned}
$$

Последнее слово в левом столбце прочитывается исследователями поразному и расшифровка его до сих пор находится под вопросом - в ЛН: «тому <? >» [ЛН, т. 83: 155], в Д30 и «Летописи жизни и творчества Ф. М. Достоевского»: «Тону<? ?» (Д30; 27: 91), [Летопись, I: 346].

Также в левом столбце написано имя «Настасья Петровна». В комментариях к публикации $3 K_{1}$ и в ЛН, и Д30 сказано, что личность Настасьи Петровны не установлена [ЛН, т. 83: 170]; (Д30; 27: 357). Мы предполагаем, что имеется в виду жена П. А. Давыдова, семипалатинского приказчика, с которым Достоевским дружил во время ссылки. «Достоевский обещал оказать Давыдову содействие в отыскании места в Петербурге или Москве» (см.: [Белов, I: 225]). 14 октября 1859 г. Достоевский отправил письмо Давыдову, в котором извинялся, что долго не писал, и упомянул о своем обещании: «...на будущий год искать нечего. Но в будущем году, если Вы позволите мне, я буду работать для Вас, и в будущем году надежды могут иметь успех. $<\ldots>$ если что и сообщу Вам в течение будущего года, то сообщу точно и положительно, а не легкомысленно. <...> На письмо Ваше отвечу более подробно чем теперь; ибо теперь имею в виду только уведомить Вас о главном деле. Большой поклон мой Настасье Петровне» (Д30; 28,: 355). Таким образом, в конце 1859 г. Достоевский обещал подыскать работу Давыдову не в будущем 1860 г., а в следующем 1861 г. Имя Давыдова упоминается еще раз в письме А. И. Гейбовича, тоже знакомого Достоевского по Семипалатинску, от 25 марта 1860 г.: «Петръ Андрпевичъ Давыдовъ, прикащикъ Купиа Полякова, писаль ко мнг чтобъ увпдомить его объ вашемъ Адресп, но что я могу сообщить ему, когда самъ пишу наугадъ» ${ }^{10}$. Больше писем Достоевского к Давыдову, как и к Гейбовичу не обнаружено, возможно, оба (Давыдов и Достоевский) потеряли координаты друг друга. Быть может, Достоевский и планировал написать Давыдову или его жене в конце 1861 г. (записи на с. 47 датируются именно этим временем), так как подошел срок его обещанию.

«Вторая» записная книжка (ОР РГБ. Ф. 92.І.2.7 - далее $3 K_{2}$ ), датируемая предположительно концом 1862 - второй половиной 1864 г. ${ }^{11}$, содержит записи литературного и литературно-критического характера, расчеты, связанные с издательской деятельностью, росписи номеров журнала «Эпоха». Так, на с. 32, несмотря на то, что в заголовок вынесено «ююльская книжка», 
дан перечень авторов и статей июльского и августовского номеров «Эпохи» за 1864 г. Компоновка номеров была подвижной, одни статьи оставались, другие были напечатаны в следующих номерах (см. Илл. 8).

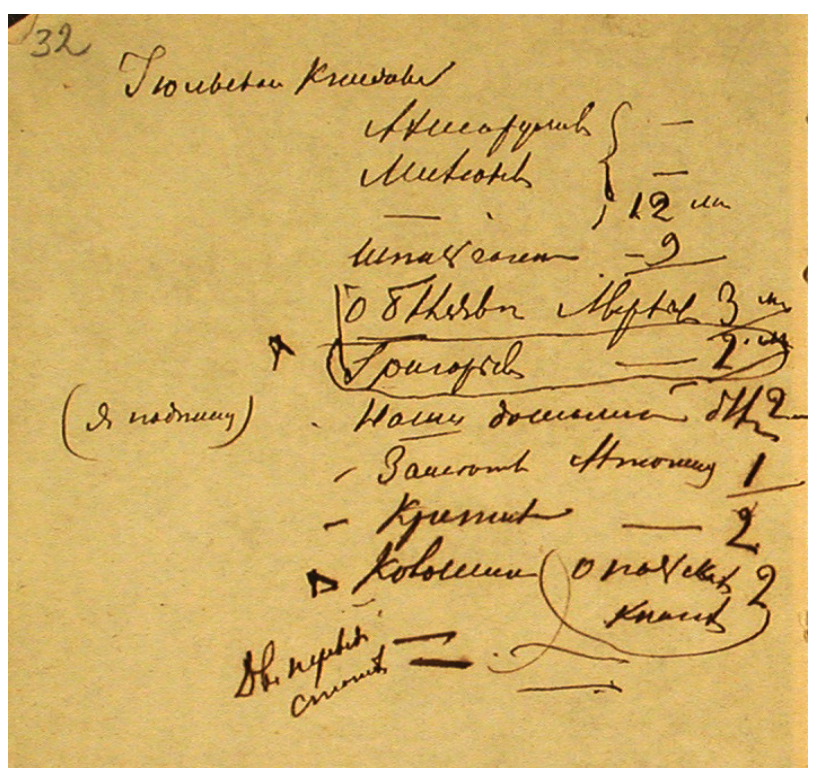

Илл. 8. С. $323 K_{2}$

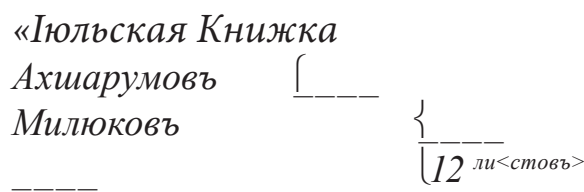

Шиильгагенб 9

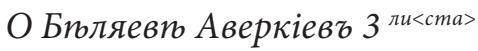

Григорьевб 2 ли<стах

(я подпишу) [?] Наши домашнія дюла $2<$ листа>

- Зампткки Лптописи $<a>$

- Критика

$$
\frac{1}{2}<\pi u c m a>
$$

Колочинъ о польскихъ книгахъ $2<$ листа>

Двг перевод<ныя > статейки

По поводу записи «О Бпляевю Аверкіевъ» в комментарии ЛН сказано: «О какой статье идет речь - неясно» [ЛН, т. 83: 193]. Позже В. С. Нечаева уточнила: «Вероятно <...> Аверкиев написал большую работу о трудах проф. И. Д. Беляева, специалиста по древнерусскому праву, быту, хозяйству и технике, собирателя древнерусских юридических актов, защитника прав крестьян на землю на общинных началах. В 1859 г. вышел труд Беляева 
“Крестьяне на Руси”, а в 1864-1865 гг. - “Судьбы земщины и выборного начала на Руси”. Составляя план июльской книги “Эпохи”, Достоевский записал: “О Беляеве Аверкиев - 3 листа”. Однако эта статья в “Эпохе” не появилась» [Нечаева, 1975: 152]. Стоит добавить, что вторая работа Беляева еще не была известна в то время, когда делалась эта запись, часть работы была опубликована при жизни автора в 1867 г.: «Земские соборы на Руси», полностью же книга «Судьбы земщины и выборного начала на Руси» вышла только в 1905 г. [Каплин: 24]. Скорее всего, Достоевский поручил Аверкиеву (как он уже делал в случае со статьей о Костомарове) написать обзор трудов или статью об историке Беляеве, работы которого, особенно докторская диссертация «Крестьяне на Руси. Исследование о постепенном изменении значения крестьян в русском обществе» (М., 1860), оказали влияние на проведение крестьянской реформы и стали ее теоретической основой. Крестьянской реформе в журналах «Время» и «Эпоха» уделялось огромное внимание. Не исключением стал и 1864 г. Как пишет В. С. Нечаева, «в первых пяти книгах “Эпохи” не было раздела, посвященного внутренней жизни страны, хотя <...> помещались отдельные статьи, отзывавшиеся на проведение крестьянской реформы, организацию земских учреждений, подготовку реформы суда» [Нечаева, 1975: 39]. В июньской книжке «Эпохи» за 1864 г. в разделе «Наши домашние дела» было обещано, что в следующих обозрениях будет обсуждение «Устава земских учреждений», о которых было много споров во времена крестьянской реформы [Нечаева, 1975: 40]. Крестьянской реформе был посвящен и ноябрьский выпуск раздела «Наши домашние дела», где давался «отклик на опубликованный “Обзор действий Министерства внутренних дел по крестьянскому делу”» [Нечаева, 1975: 43].

Возникает вопрос, что же помешало Аверкиеву написать такую статью? По рукописи видно, что запись ниже «Григорьевъ - 2 л.» обведена в овал (см. Илл. 8). В комментарии ЛН сказано, что здесь имеется в виду статья И. Долгомостьева «Заметки по истории книжного (школьного) просвещения в России», которая была подписана «Ив. Григорьевъ» [ЛН, т. 83: 193]. Однако если посмотреть на росписи тех же номеров журнала в другой тетради (РГАЛИ. Ф. 212.1.3), которую Достоевский вел параллельно с $3 K_{2}$, то можно увидеть, что работы Долгомостьева всегда значатся под его настоящей фамилией. Под фамилией Григорьев имеется в виду только один человек - Ап. Григорьев. Кроме того, на с. $863 K_{2}$ снова перечисляется состав июльского номера «Эпохи» и опять звучит фамилия «Григорьев» с тем же листажом напротив - 2 л. (см. Илл. 9). К этой записи в ЛН дан уже другой комментарий, который ближе к действительности: «Статьи Ап. Григорьева “Отживающие в литературе явления. Г-н Григорович” и “Голос старого критика”» [ЛН, т. 83: 198]. По мнению В. С. Нечаевой, Ап. Григорьев планировал написать «Третье письмо об органической критике» (первые два вышли в майском и июньском номерах), однако «редакторская цензура Федора Михайловича <...> больно задела Григорьева, и он готов был отказаться от продолжения сотрудничества <...> 
Но уже у него была подготовлена новая статья - о Григоровиче» [Нечаева, 1975: 157]. На с. $863 K_{2}$ отдельно значится фамилия «Григорьевъ», и внизу приписано «Письма объ органич<еской критикъ>». Вот как выглядит разворот книжки с двумя вариантами июльского номера «Эпохи» (именно с этого времени журнал стал печататься в типографии Н. Тиблена).

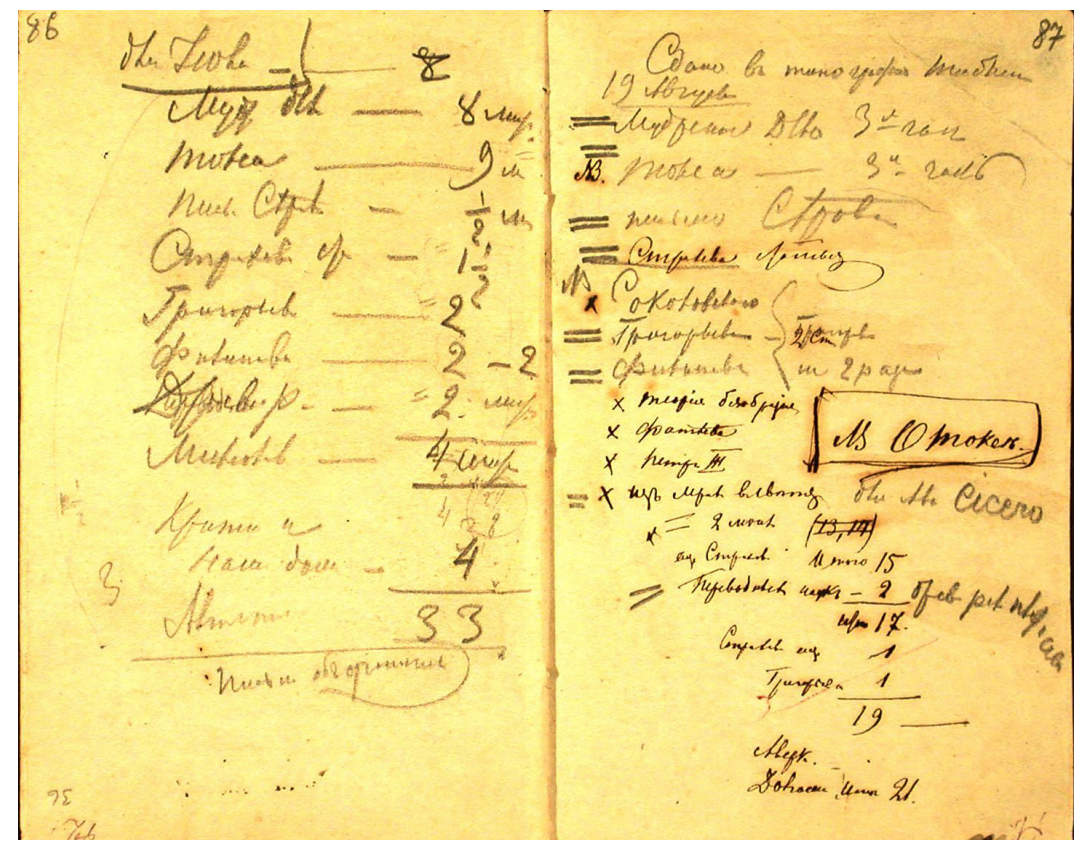

Илл. 9. С. $86-873 K_{2}$

Таким образом, на с. $323 K_{2}$ (см. Илл. 8), скорее всего, говорится о двух последних статьях Ап. Григорьева, одна из которых посвящена театру. «После смерти Григорьева театральный отдел перешел в руки его преданного ученика Аверкиева. Сотрудничать в нем он начал еще вместе с Григорьевым» [Нечаева, 1975: 166]. В этом же июльском номере выходит и статья Аверкиева, посвященная театру: «Русский театр в Петербурге. Первые три недели сезона». О преемственности двух статей, Григорьева и Аверкиева, также пишет В. С. Нечаева (см.: [Нечаева, 1975: 166-167]). Кроме того, на с. 32 видим, что Достоевский обводит фамилию «Григорьевъ» и проводит стрелку к фамилии «Аверкіевъ» (см. Илл. 8). Можно предположить, что это сделано уже после смерти Григорьева (умер 25 сентября 1864 г.). Ведь именно Аверкиев написал статью об умершем Ап. Григорьеве, она вышла в следующем, 8 номере «Эпохи» (ц. р. получено 22 октября) под названием «Аполлон Александрович Григорьев».

Также на с. 32 3К 2 есть помета Достоевского «Я подпишу» (см. Илл. 8). Она тоже осталась под вопросом в комментарии к первой публикации, кроме 
того, в публикации ЛН она воспроизведена между фамилией «Григорьев» и записью «Наши домашние дела», причем таким образом, что напротив нее находится пустая строка [ЛН, т. 83: 180]. Однако запись «Я подпишу» сделана прямо напротив названия раздела «Наши домашние дела». Известно, что этот раздел вел во «Времени» сначала А. У. Порецкий, затем с октябрьского номера 1862 г. его сменил А. Е. Разин, после открытия «Эпохи» в 1864 г. раздел снова был поручен Порецкому: по мнению В. С. Нечаевой, Порецкий, несомненно, принимал участие в составлении первых трех обозрений [Hечаева, 1975: 39]. Первое обозрение вышло, однако, только в июньском номеpe, так как Порецкий выполнял и другие дела редакции («как официальный редактор Порецкий прочитывал готовящиеся книги, подписывал объявления от редакции, имел дело с цензурой» [Нечаева, 1975: 18]). Несколько обозрений, по-видимому неудачных, написал О. А. Филиппов. В. С. Нечаева приводит письмо Ф. М. Достоевского к Порецкому, датируемое концом ноября - началом декабря 1864 г., в котором Федор Михайлович ““умоляет” Порецкого поскорее написать "Внутреннее обозрение” для ноябрьской книги, так как Филиппов “написал ужасную дичь", а номер надо “выдать до Рождества"» [Нечаева, 1975: 33] ${ }^{12}$. Последнее обозрение в декабрьском номере «Эпохи» за 1864 г. Нечаева приписывает двум авторам, одним из которых, по ее мнению, был Ф. М. Достоевский (см.: [Нечаева, 1975: 33, 44]). Участие Достоевского, возможно, было более активным, чем мы предполагаем.

К помете «Критика - 2 л.» (см. Илл. 8) в ЛН находим следующий комментарий: «В № 8 “Эпохи” критических статей нет. Возможно, что у Достоевского описка и он имел в виду отдел “Политика" (анонимный)» [ЛН, т. 83: 193]. Во-первых, в расшифровке неправильно воспроизведен листаж предполагаемой «Критики»: на самом деле цифра 1, находящаяся напротив «Заметок летописца», относится к цифре 2, находящейся напротив слова «Критика». Получается: «Критика - 1/2<листа>». Достоевский именно так прописывает дроби (см. Илл. 9). Во-вторых, необязательно имеется в виду августовский номер: на с. 32 представлен черновик содержания июльского номера, и только некоторые работы из него перешли в августовский. $\mathrm{B}$-третьих, с таким листажом (1/2 л.) на с. $863 K_{2}$ (где дана более подробная роспись июльского номера) в списке статей значится «Пись $<\mathcal{M o}>$ Сrьрова» (см. Илл. 9), а именно: «Заметка современного знаменитого мыслителя (из немузыкантов) о Девятой симфонии Бетховена» (вышла в июльском номере «Эпохи»). Это перевод небольшой заметки известного философа-теолога Давида-Фридриха Штрауса (1808-1874) о Девятой симфонии Бетховена с послесловием А. Н. Серова [Нечаева, 1975: 172].

Следующая запись на с. 32: «Колошинъ о польскихъ книгахъ - 2 л.» (см. Илл. 8) оставалась до недавнего времени без комментария. По предположению В. Н. Захарова, здесь имеется в виду статья под рабочим названием «Польша и ее конфедерация», отмеченная в записной тетради Достоевского 1864-1865 гг. (РГАЛИ. Ф. 212.1.3. С. 14) [Захаров, 2013b: 60]. 
И последняя запись на с. 32: «Двпь перевод<ньяя> статейки» (см. Илл. 10). Какие статьи имеются в виду? Подсказка, возможно, находится на соседней странице рукописи (с. 33), где в самом низу теми же чернилами, что и записи на с. 32, сделана помета: «Со Страховы <мъ>. О переводн<ыхъ > Cтатьяхъ». Остальные записи на с. 33 сделаны карандашом, видимо, в другое время.

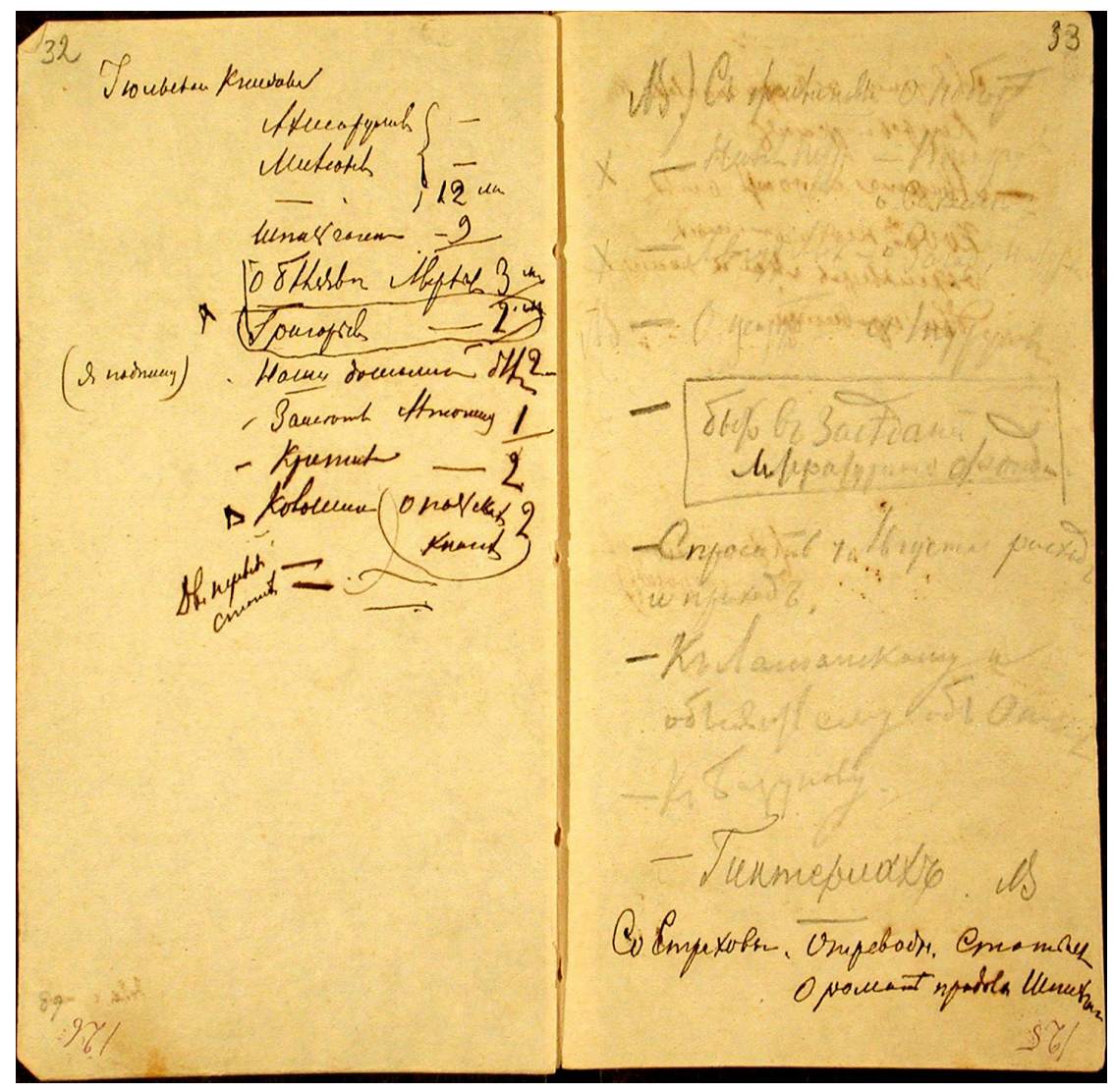

Илл. 10. С. $32-333 K_{2}$

Как утверждает В. С. Нечаева, в «Эпохе» не планировался специальный отдел «Статьи ученого содержания», однако все же появились работы, которые в записных книжках и тетрадях Достоевского этого периода получили рабочее название «переводные науки» [Нечаева, 1975: 98]. Н. Н. Страхов с первого по третий номер «Эпохи» поместил ряд переводных и компилятивных статей, например, перевод из Г. Гейне «Черты из истории религии и философии Германии» (см.: [Нечаева, 1975: 101]). В ряде выступлений Страхов пропагандировал работу Ж. Э. Ренана (1823-1892) «Жизнь Иисуса». В августовской книге за 1864 г. в «Заметках летописца» 
он опубликовал изложение политических взглядов Ренана на французскую революцию. Имеется в виду работа Э. Ренана «Еssais de Morale et de Critique» («Этические и критические очерки»; 1859 г.): «Есть основание думать, пишет В. С. Нечаева, - что самим Страховым (или по его инициативе) в “Эпохе” были помещены переводы двух статей Ренана...» [Нечаева, 1975: 102]. Речь идет о статье Ренана «Высшее обучение во Франции, его история и будущность» (опубликована в пятой книге «Эпохи» за 1864 г.) и статья «Древние религии» (опубликована в седьмой книге). На с. $863 K_{2}$ (см. Илл. 9) поверх записи «Переводн<ыя >c<maтьи>» уже вписано: "Древн<ія>p<елигіu>». Таким образом, под записью «Двпь перевод<ныя> статейки» Достоевский мог иметь в виду будущую публикацию в 7 номере «Эпохи» за 1864 г. работы Э. Ренана «Древние религии», а также изложение взглядов Ренана на французскую революцию в «Заметках летописца» Н. Н. Страхова в августовском номере.

На с. 33 3К 2 карандашом записан список дел по изданию очередного номера «Эпохи» с именами и фамилиями людей, с которыми эти дела нужно решить (см. Илл. 11). Среди них есть запись, которая в ЛН и Дзо была прочитана как «Никол<ай> Петр<ович> Второв о векселе» [ЛН, т. 83: 181]; (Д30; 27: 92). В комментариях к обеим публикациям сказано, что личность Второва не установлена [ЛН, т. 83: 194]; (Д30; 27: 358). С. В. Белов считает, что, скорее всего, имеется в виду какой-то кредитор Достоевского по журналу «Время» [Белов, I: 164].

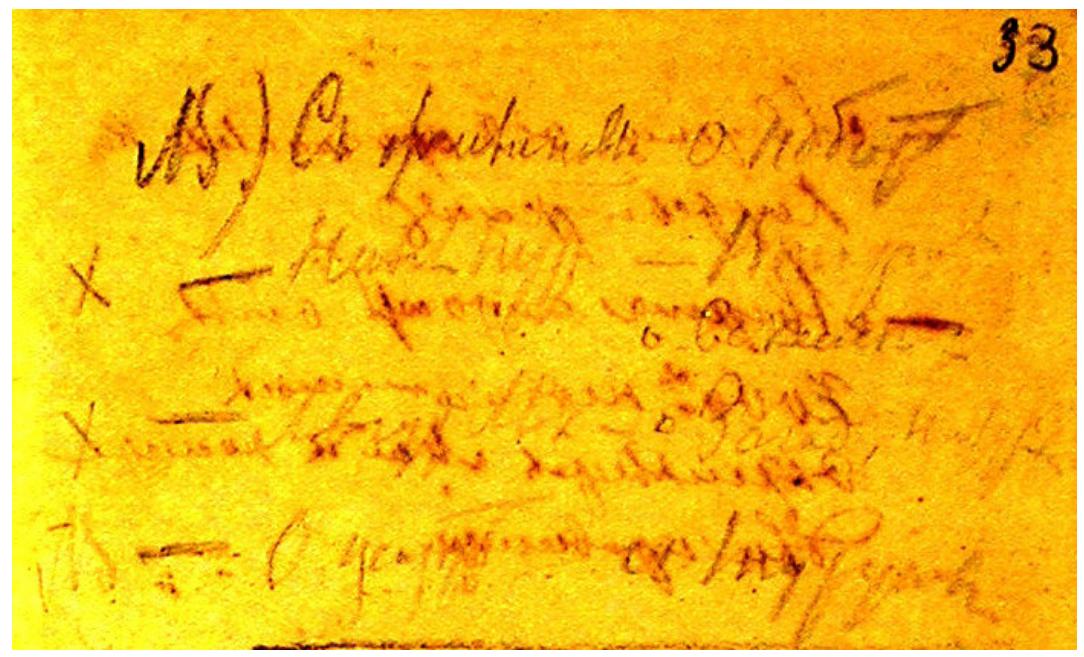

Илл. 11. Фрагмент с. $333 K_{2}$

Во-первых, записи на с. 33 относятся ко времени выхода журнала «Эпоха». Во-вторых, нам показалось странным, что в рукописи фамилия «Второв» отделена от имени с отчеством тире. Вся запись, по нашему мнению, читается следующим образом: 
«NB.) Съ Филиповы $<\mathcal{M r}>$ о набори

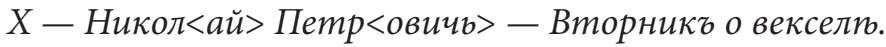

$X-$ Августь Алек<сандровичь $>-о$ Загад<очныхъ > натурахъ.

$N B-O$ цензурь - съ Турунов <ымъ $>$ ».

Написание буквы «к» с верхним выносным штрихом «без ответвлений», особенно в конце слов, когда не прописывается не только конечный «ъ», но и «съедается» промежуточная гласная (превращается в еле заметную точку), характерно для почерка Достоевского. Сравним, например, с написанием буквосочетания «къ» на конце слов «желчевикъ», «Такъ», «доносчикъ», «человпкъ» в $3 K_{1}$ и $3 K_{2}($ Илл. 12).
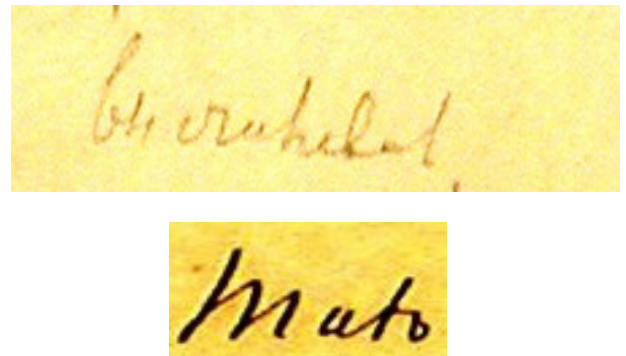
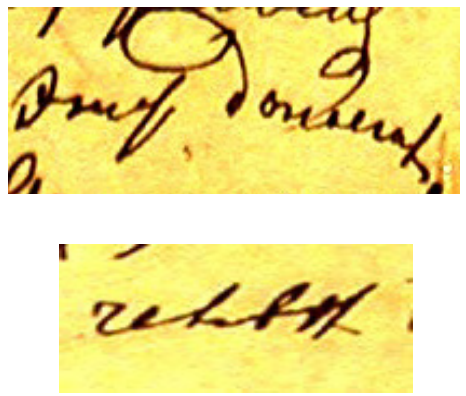

Илл. 12. Фрагменты с. $913 K_{1}$ и с. $6,18,473 K_{2}$

Вероятно, ошибка возникла из-за того, что в «Летописи...» упоминается нотариус по фамилии Успенский-Второв, который 11 октября 1864 г. «переписывает» вексель Достоевского, выданный купцу Леониду Николаевичу Демису (см.: [Летопись, I: 482]). Второй раз фамилия Успенского-Второго звучит во втором томе «Летописи...» [Летопись, II: 23]. Однако имя и отчество этого нотариуса совсем другие, чем в нашей записи, - Михаил Иванович. Действительно, нотариус Михаил Иванович Успенский (без двойной фамилии) жил в Петербурге на Невском проспекте (дом 51, кв. 9) ${ }^{13}$. Если мы обратимся непосредственно к векселю, выданному Достоевским, то фамилия нотариуса, указанная в «Летописи...», читается по-другому: Нотариусъ М. Успенскій-Второй (см. Илл. 13), т. е. никакого нотариуса по фамилии «Второв» не было.

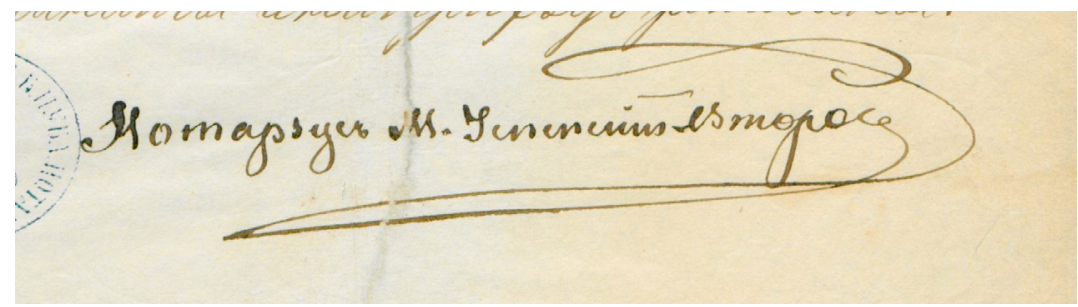

Илл. 13. Вексель. Фрагмент (ИРЛИ. Ф. 29510. Л. 8) 
Таким образом, следует искать нотариуса или кредитора этого периода с именем Николай Петрович. Возможно, имеется в виду сын А. И. Рейслер, известной кредиторши Ф. М. Достоевского, - Николай Павлович, который занимался делами своей матери и позже, в 1867 г. (см.: [Белов, II: 145]). Достоевский мог просто ошибиться в отчестве молодого человека.

Рассмотрим еще одну запись с этой страницы: «О иензург -cъ Турунов<ымъъ>». В некоторых исследованиях наблюдается расхождение в имени цензора. В печатных изданиях (в комментариях ЛН, Д30, «Летописи...», в монографиях В. С. Нечаевой) он значится как Михаил Николаевич Турунов. В энциклопедии С. В. Белова смешаны биографии двух людей: Якова Николаевича Турунова и Михаила Николаевича Турунова [Белов, II: 328]. В статье Б. Н. Тихомирова и Е. Д. Маскевич «Из юных лет Михаила и Федора Достоевских...» эта ошибка уже исправлена (см.: [Маскевич, Тихомиров: 66, 7273]) и указано, что «Я. Н. Турунов (1811-17.01.1873) был старшим братом М. Н. Турунова. В службу он вступил в 1831 г.; в 1864 г. получил чин действительного статского советника, вышел в отставку в 1870 г.» [Маскевич, Тихомиров: 73].

Действительно, в «Адрес-календарях», начиная с 1847 г., значатся оба Турунова: Яков Николаевич и Михаил Николаевич. В 62 т. «Сборника Императорского Русского Исторического Общества» о Я. Н. Турунове сказано следующее: «Туруновъ, Яковъ Николаевичъ, д. с. с., преподаватель исторіи въ военно-учебныхъ заведеніяхъ, сотрудникъ Военного Сборника и Русского Инвалида, ученый секретарь бывшаго военно-ученаго комитета» ${ }^{14}$. Эта же информация повторяется в «Общем штате Российской империи на 1847 г.» $»^{15}$.

Михаил Николаевич Турунов (1814-1890) - действительный тайный советник, сенатор. В «Адрес-календаре» на 1866-1867 гг. (ч. 1) именно он числится в членах совета Главного управления по делам печати (С. 334), а на 1865-1866 гг. (ч. 1) - председателем Санкт-Петербургского Цензурного комитета (С. 318). Подробнее см.: [ЛН, т. 83: 194], (Д30; 20: 358), [Нечаева, 1975: 70], [Гринченко: 364-394], [Мезьер: 113]. Можно обратиться к материалам по биографии и творчеству Н. А. Некрасова, который тоже общался с цензором М. Н. Туруновым (см.: [ЛН, т. 49-50: 477; т. 51-52: 532]).

На с. 34 осталась без комментария запись: «- О Токег - (Долгомостьева спросить)» (см. Илл. 14). 


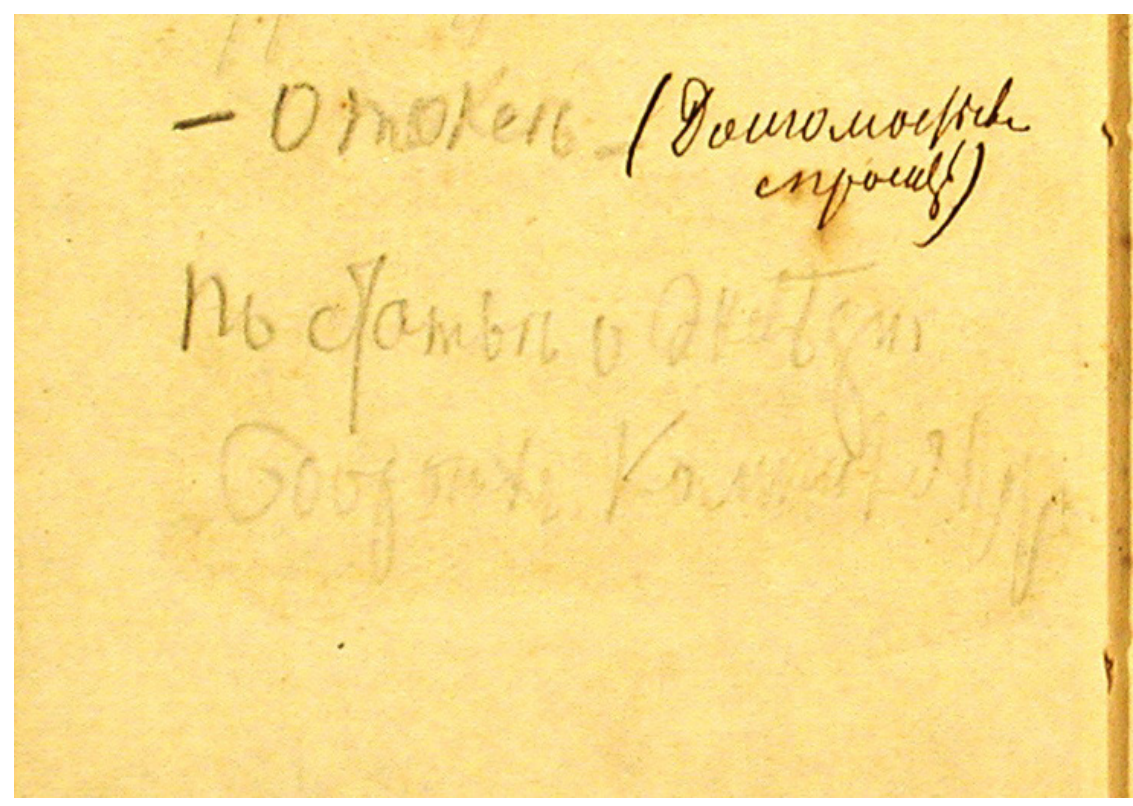

Илл. 14. Фрагмент с. $343 K_{2}$

Переводчиком «Токеи» (полное название - «Токеа, или Белая роза. Повесть из последней англо-американской войны» (в трех частях)) был Александр Карлович Герих. Перевод А. К. Гериха публиковался в особом приложении к журналу «Эпоха» в 1864 г. в следующих номерах: 5 (май, стр. 1-158), 6 (июнь, стр. 159-306) и 7 (июль, стр. 307-470). По указанию В. С. Нечаевой, беловой автограф 36, 37 и 38 глав перевода, хранящийся в ОР РГБ (ф. 93. III.8.10), значится как принадлежащий М. М. Достоевскому [Нечаева, 1975: 95].

На самом деле в фонде ОР РГБ содержится четыре главы $(35$, без нескольких первых абзацев, 36, 37, 38). Текст рукописи полностью совпадает с текстом опубликованных глав в седьмом номере «Эпохи» за 1864 г. (ц. р. получено 19 сентября, опубликовано 29 сентября 1864 г.) Роман Ч. Сильсфильда, судя по титулу первого издания, был написан на английском языке, несмотря на то, что в основном этот автор писал на немецком. В энциклопедии Брокгауза и Ефрона находим следующую информацию: «Сильсфильд (Чарльз Sealsfield) - псевдонимъ писателя Карля Постля, род<ился> въ 1793 г. До 1823 г. былъ монахомъ въ Прагъ, затьмъ уъхалъ въ Съв<ерную> Америку, гдъ принял имя С<ильсфильдъ>. Въ 1828 г. С<ильсфильдъ > выступиль на литературное поприще романомъ “Tokeah or the white rose". Этотъ романъ, какъ и другіе писанные на нъмецк<омъ> яз<ыкъ>, обнаруживаетъ у автора живое воображеніе и недюжинный описательный талантъ...» [Брокгауз, Ефрон, XXIX ${ }^{\text {a }}$ (58): 895]. Далее перечислены названия произведений этого автора на немецком языке и сказано, что была также осуществлена переработка романа «Токеа, или белая роза» на немецкий 
язык, но роман вышел в 1838 г. под другим названием: «Der Legitime und die Republikaner» [Брокгауз, Ефрон, XXIX ${ }^{a}(58):$ 896]. Приводим фото титулов обеих книжек на английском и немецком языках (см. Илл. 15).

TOK EAH;

or,

\section{THE WHITE ROSE.}

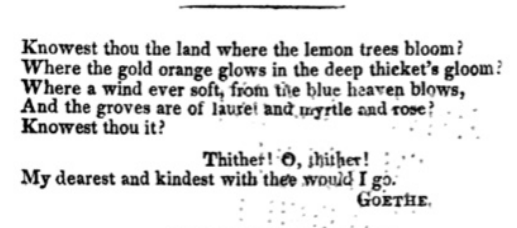

IN TWO VOLUMES.

VOL. II.

PHILADELPHIA:

CAREY, LEA \& CAREY, - CHESNUT STREET.

SOLD, IX XEW YORK, BY G. \& c. CARVILL, - IX BOsTos, BY MUXROE \& FBuXcis.

$\overline{1829 .}$

\section{(E) fammelte Werke}

yon

\section{Gharles Sealşiels.}

\author{
Sweiter abetl. \\ Der fegitime und die Tepublikaner. \\ 3weiter Theil.
}

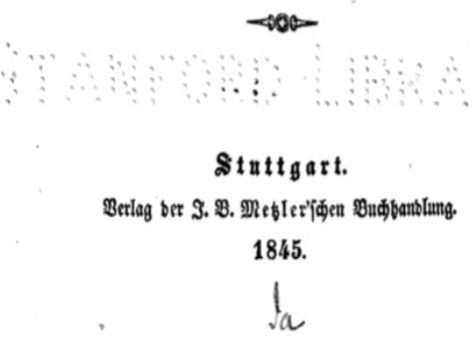

Илл. 15. Титулы изданий романа «Токеа, или белая роза» на английском и немецком языках

Мог ли М. М. Достоевский переводить только несколько глав, но с немецкой адаптации, так как английского языка он не знал? Или Михаил Михайлович перевел все, но сохранился перевод только нескольких последних глав (всего 43 главы)? Мог ли Достоевский просто переписать эти главы (или весь текст, но он не сохранился) на чистовик для типографии, так как рукопись содержит типографские пометы? Или это выполнил другой человек? Если перевод был сделан М. М. Достоевским, то почему за работу, судя по гонорарной ведомости, заплатили А. К. Гериху: «29 октября <1864 2.>»: «Г. Гериху за Токею 203 р. 15 к.» (ОР РГБ. Ф. 93.I.3.21. С. 123). По 
мнению публикаторов книжки в 83 томе ЛН, Герих, вероятно, делал и другие переводы для журнала «Эпоха» [ЛН, т. 83: 239].

Июньский и июльские номера «Эпохи» за 1864 г. выходили в августе и сентябре, уже после смерти Михаила Михайловича [Нечаева, 1975: 256-257]. В записной тетради 1864-1865 гг. сохранилась запись Ф. М. Достоевского от 23 августа: «О переводчикп съ Англійскаго для Токеи» (РГАЛИ. Ф. 212.І.3. С. 145). А 28 октября в той же тетради уже записано: «Отослать деньги Токеа» (РГАЛИ. Ф. 212.I.3. С. 136; см. также: [ЛН, т. 83: 201, 204-208, 235, 238-239]). Известно одно письмо А. К. Гериха с просьбой выплатить остатки гонорара за перевод: «Въ письмп оть 29은 Октября прошедшаго года, за № 403, редакція обющзала выслать мню недосланные 200 руб. за мой переводъ “Токеа или бплая Роза" никакъ не позже Января мпсяи, 1865 года» (РО ИРЛИ. Р. І. Оп. 6. № 132. Л. 1) ${ }^{16}$. А. К. Герих получил указанный гонорар 29 октября, однако это был предварительный расчет. В своем письме Герих требовал доплатить «недосланные» ему 200 руб. и напомнил, что редакция обещала сделать это не позже января 1865 г. Деньги, вероятно, были выплачены полностью, так как больше писем Гериха с требованием денег не поступало или они не сохранились (см. также: [Летопись, II: 19]).

Таким образом, атрибуция этого текста остается под вопросом, необходимо провести почерковедческую экспертизу сохранившихся рукописных глав и установить степень участия М. М. Достоевского в переводе данного романа.

По поводу записи «По статью о желюзн<ыхъ> дорогахъ компиляторъ» (см. Илл. 14) в примечаниях к первой публикации сказано, что такой статьи в «Эпохе» в 1864 г. помещено не было [ЛН, т. 83: 194]. В монографии В. С. Нечаевой находим, что эта тема была озвучена в рубрике «Наши домашние дела»: «В августовской и сентябрьской книгах продолжалось обсуждение постройки южной железной дороги, приводились расчеты ее стоимости в условиях России и за границей, отмечалась порочная практика акционерных обществ, спекуляции подрядчиков, вносились предложения с целью ускорить и удешевить постройку железных дорог» [Нечаева, 1975: 41].

На с. 87, где продолжается составление августовского номера «Эпохи» за 1864 г. осталась без комментария запись: «x Петрь III» (см. Илл. 9). В комментариях к публикации в ЛН сказано: «Статья о Петре III ни в этом, ни в следующих номерах “Эпохи” напечатана не была» [ЛН, т. 83: 198]. В записной тетради 1864-1865 гг. эта запись повторена: «- Cmamью о Петрг 3. дать Порьицкому 一» (РГАЛИ. Ф. 212.1.3. С. 143). Б. Н. Тихомиров атрибутирует эту статью историку Петру Николаевичу Петрову, чей адрес Достоевский записывает в «третьей» ЗК (ОР РГБ. Ф. 93.І.2.8 С. 38). В комментарии к адресу историка Б. Н. Тихомиров пишет: «О контактах в 1860-е гг. Достоевского с историком П. Н. Петровым (1827-1891) биографам писателя ничего не известно, но стоит указать, что в редакционном архиве журнала “Время” находилась предложенная для публикации братьям Достоевским 
рукопись “Исторический очерк событий в России с 1742-1762", автором которой указан Петров (весьма вероятно, что Петр Николаевич), зарегистрированная в Редакционном журнале в рубрике "Статьи серьезного (ученого) содержания” под № 29/50. И, видимо, о ней Достоевский сделал 25 августа 1864 г. памятную запись: “Статью о Петре III Порецкому (очевидно на рецензирование)”» [Тихомиров, 2018: 86].

В «третьей» записной книжке, датируемой 1864-1865 гг. (далее $3 K_{3}$ ), на c. 2 находим наброски для «политической статьи», которую Достоевский, видимо, какое-то время вынужден был писать сам. Запись местами угасла и не была расшифрована полностью в первых изданиях (см. Илл. 16):

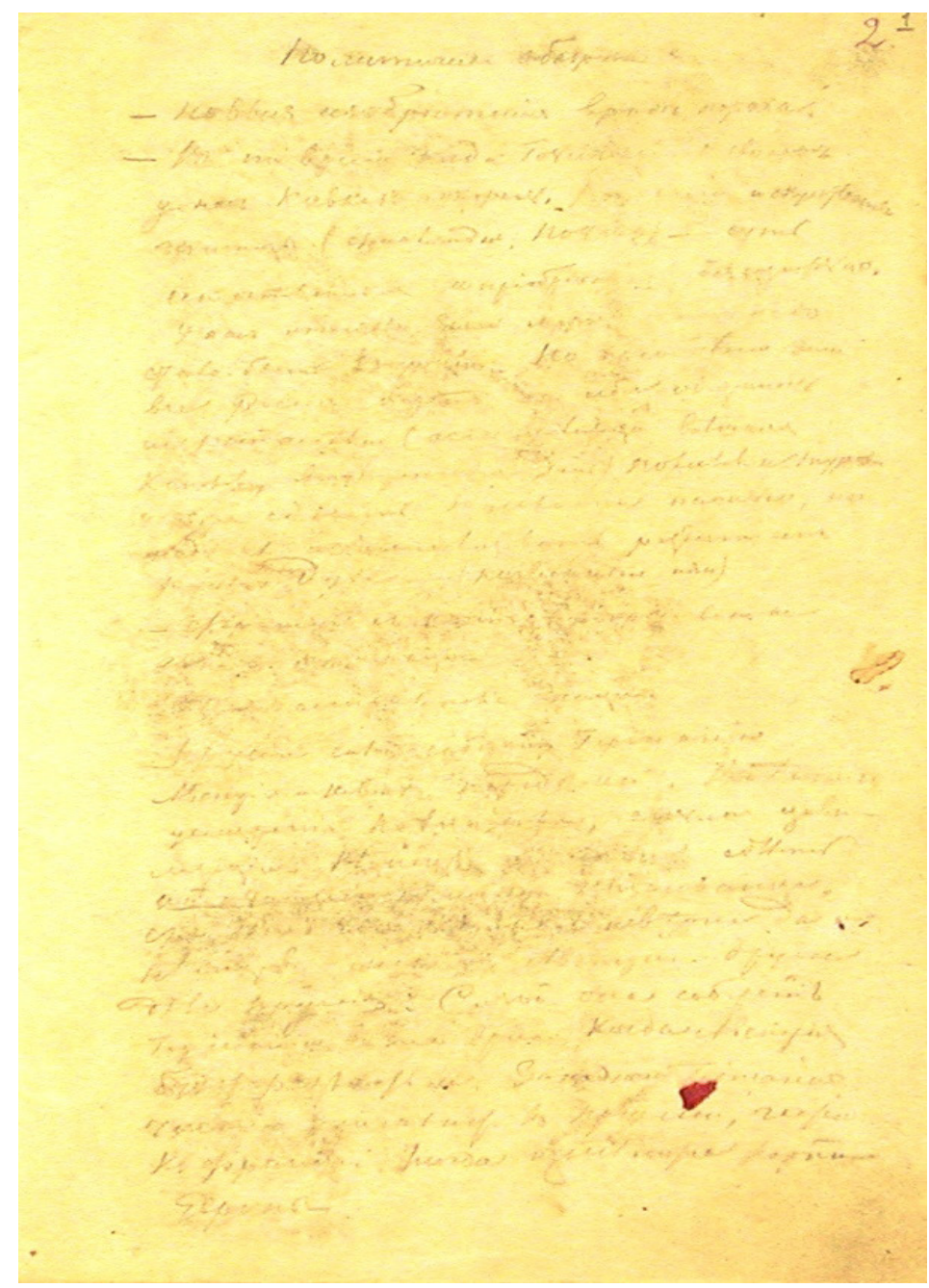

Илл. 16. С. $23 K_{3}$ 
Уточним расшифровку (полужирным начертанием выделены не прочитанные в первых публикациях фрагменты, разночтения также отображены в сносках):

«Политическое обозртніе

Новыя изобрптенія вроди пороха.

- Въ то время когда Гольштейнъ со Шлезвигомъ у насъ Кавказъ покоренъ ${ }^{17}$. Вспь наши искусственныя границы (Финляндія, Польша) - суть естествен-

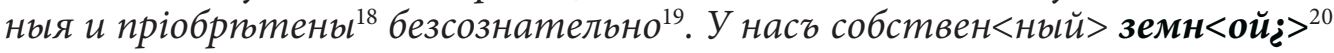
мірь и намь надо стало-быть Туриію. Но пріобрптя это все Россія береть на себя обязанность міростяжателя ${ }^{21}$ (ассимиляція внпиняя Катковб, внутренняя - День <)>. Поляковъ и турокъ нельзя сдплать русскими насильно, но надо ихъ ассимилировать развитіемъ русскаго духа (почвенныя идеи) - Франція св ней Австрія всп не едины. Это націи... Цивилизованные націи $<\dot{i}>22$.

- Пруссія силой собереть Германію<.> Австрія и швахъ передъ ней. Внюшнія ухишренія. Новая нація, - сильная иивилизація. Нюмиы же должны сдюлать [отказб оть] новую иивилизацію. Стало-быть все дюло есть въ невпріи да и нюмиевъ мало для Австріи ${ }^{23}$. Другое дюло Пруссія. Силой она собереть Германію, въ то время когда Австрія будеть разлагаться. Западная Германія частію примкнеть къ Пруссіи, частію къ Франціи: Тогда измпнится карта Европь».

На с. $33 K_{3}$ записаны адреса (см. Илл. 17), первые два из которых прочитаны так: «Итальанск<ая>, домъ Салтыкова, 27 № квартиры Ар. Мих.» и «Столярны<й>, Головинскаго И. Сид.<i> [Тихомиров, 2018: 77]. Ранее

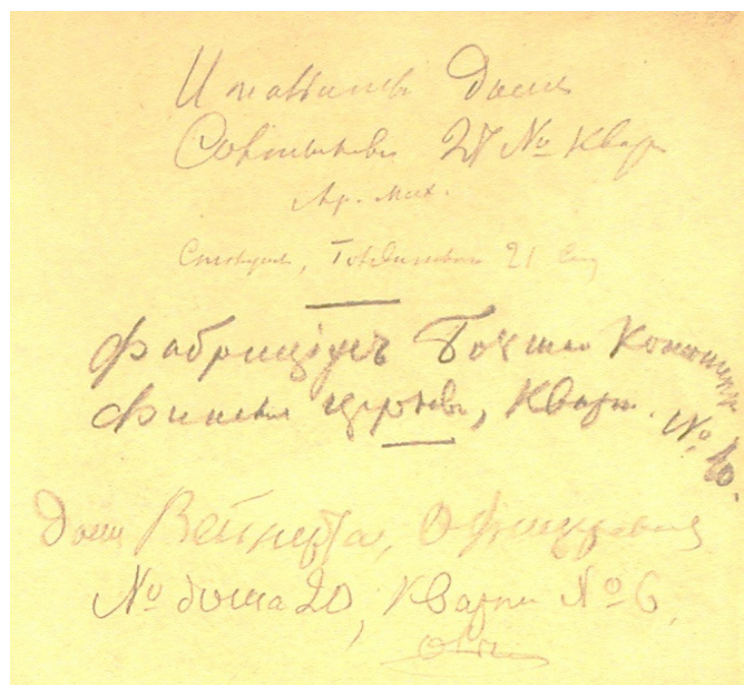

Илл. 17. Фрагмент с. $33 K_{3}$ 
Т. И. Орнатская увидела в этой записи два адреса, причем последний воспроизведен ею так: «Столярный, Головинского И. Ст.» [Орнатская: 20].

Нам кажется, что в последней строчке имеется в виду не сокращенная фамилия И. Сид. или И. Ст., а опять-таки, как и в случае со Второвым, указание на дату: 21 Сент<ября>». Сравним написание цифры «21» в этой же $3 K_{3}$ (см. Илл. 18):

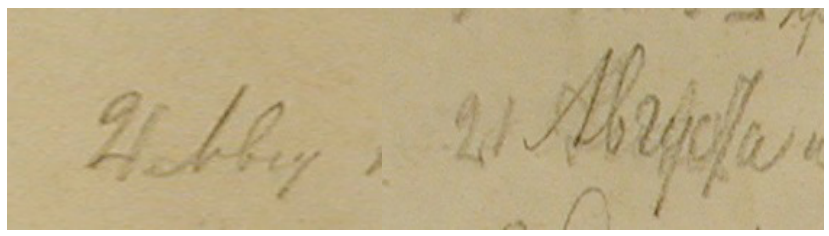

Илл. 18. Фрагменты с. 21 и $403 K_{3}$

Ниже на этой же странице записан адрес: «Фабриціусъ Большая Конюшенная Финская церковь, кварт. № 10» (см. Илл. 17). У Т. И. Орнатской сказано, что имеется в виду автор статьи «Записки ${ }^{24}$ о начале почты в России. (В память 200-летия почтового ведомства в России)» [Орнатская: 20]. Статья была опубликована в 10 номере «Эпохи» за 1864 г. В росписи журнала восстановлены инициалы автора: А. К. Фабрициус [Нечаева, 1975: 258]. Б. Н. Тихомиров указывает другое имя: «В каталогах ряда центральных библиотек (РНБ, РГБ, ГПИБ) автор статьи (в форме оттиска) описан, без указания источника, как Адальберт Карлович Фабрициус. Однако, согласно адресной книге середины 1860-х гг., по указанному адресу проживал Генрих Карлович Фабриииус, в то время как Адальберт Карлович в справочнике отсутствует. <..> Можно допустить, что Генрих и Адальберт - братья, жившие по одному адресу. Но возможно, что в библиотечные каталоги вкралась ошибка, и автором публикации является Генрих-Альфонс Фабрициус (1828-1882), известный по данным Петербургского некрополя, подписавший статью своим вторым именем: Альфонс Карлович» [Тихомиров, 2018: 77-78]. Стоит добавить, что в «Адрес-календарях» на 1862-1863 и 18651866 гг. значатся оба: А. К. Фабрициус (С. 521, 348) и Г. К. Фабрициус $(307,312)$.

На с. 12 3К рядом с набросками памфлета «Офицер и Нигилистка» на полях слева вдоль страницы осталась запись, не прочитанная в первых публикациях: «восльдъ новъйшимъ убъжден<ьямъ> и Антоно<вичу> восльдъ» (см. Илл. 19). 


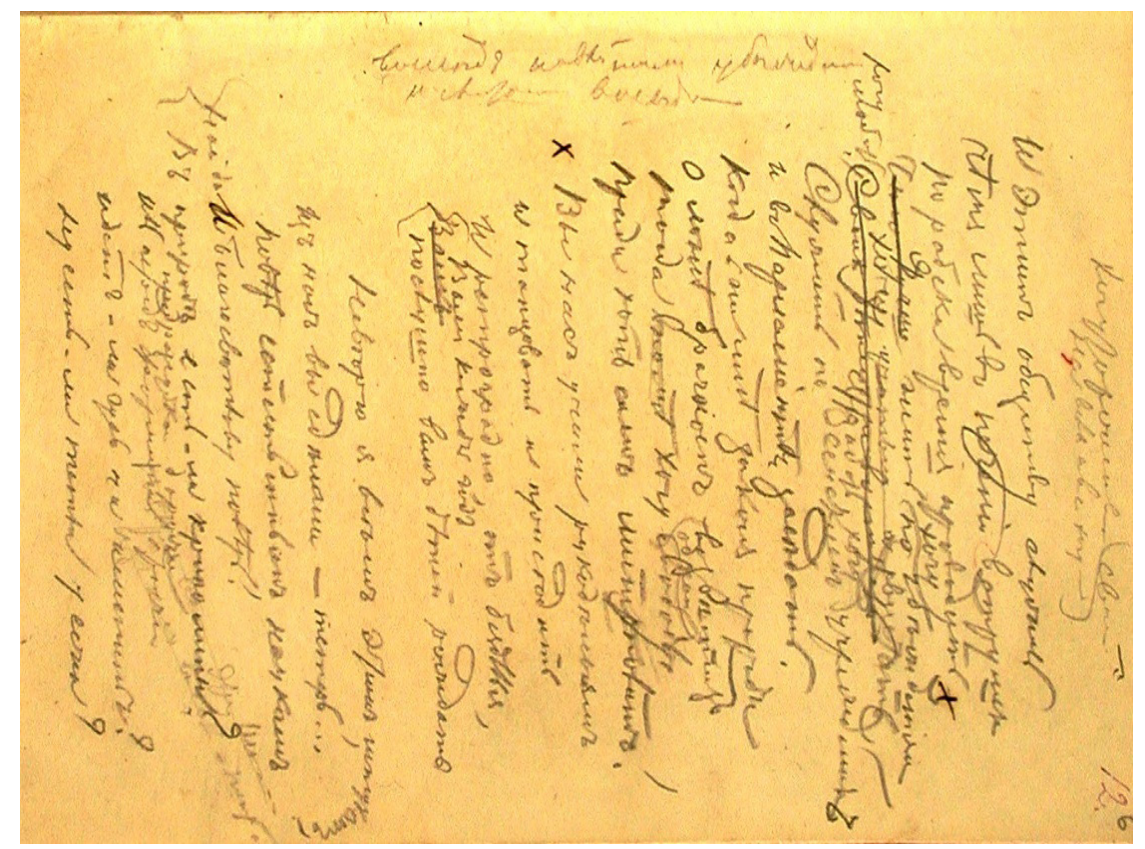

Илл. 19. С. $123 K_{3}$ в перевернутом виде

Следы полемики Ф. М. Достоевского с М. А. Антоновичем можно обнаружить во всех трех записных книжках писателя 1860-1865 гг., подробнее о характере их полемики см.: (Д30, 20: 259, 262-263, 292, 302).

В двух рабочих тетрадях, хранящихся в фондах РГАЛИ (ф. 212.1.3 и 212.1.4), которые Ф. М. Достоевский вел параллельно с $3 K_{3}$ в 1864-1865 гг., также есть редакционные записи, касающиеся последнего года существования журнала «Эпоха» и требующие изучения. Анализ этих записей позволит лучше и полнее понять характер творческой журналистской и писательской работы Достоевского.

\section{ПРИМЕЧАНИЯ}

* Исследование выполнено при финансовой поддержке РФФИ, проект «Редакционный архив журналов братьев Ф. М. и М. М. Достоевских “Время” и “Эпоха”» № 18-01290016 Достоевский.

1 См. письмо к В. Д. Констант от 10 ноября 1863 г. (Достоевский Ф. М. Полн. собр. соч.: в 30 т. Т. 28. Л.: Наука, 1985. С. 55). Далее ссылки на это издание приводятся в тексте статьи с использованием сокращения Д30 и указанием тома, книги (нижний индекс), страницы в круглых скобках.

2 Они содержат наброски к переработке «Двойника», к «Запискам из Мертвого Дома», «Скверному анекдоту», повести «Пьяненькие».

3 Подробнее о датировке см.: [Заваркина, 2018].

4 Примерные названия неосуществленных замыслов. 
5 Уже в первом «Объявлении» об издании журнала «Время» в 1861 г., вышедшем осенью 1860 г., было сказано: «Особенное вниманіе мы обратимъ на отдълъ критики. Не только всякая замъчательная книга, но и всякая замъчательная литературная статья, появившаяся въ другихъ журналахъ, будетъ непремънно разобрана въ нашемъ журналъ. Критика не должна уничтожиться изъ-за того только, что книги стали печататься не отдъльно, какъ прежде, а въ журналахъ» (Достоевский Ф. М. Полн. собр. соч.: канонические тексты / под ред. проф. В. Н. Захарова. - T. IV. - Петрозаводск: Изд-во ПетрГУ, 2000. С. 12. Далее ссылки на это издание приводятся в тексте статьи с использованием сокращения Ө. Д. и указанием тома и страницы в круглых скобках).

6 Подробнее о проблемах атрибуции в исследованиях о Достоевском см.: [Алексеева: 3-10].

7 В расшифровке записи участвовала Т. В. Панюкова.

8 Неизданный Достоевский. Записные книжки и тетради 1860-1881 гг. М.: Наука, 1971 (Литературное наследство; т. 83). Далее ссылки на это издание приводятся в тексте статьи с использованием сокращения ЛН и указанием тома и страницы в квадратных скобках.

9 В расшифровке записи участвовала Т. В. Панюкова.

10 Оригинал письма А. И. Гейбовича к Ф. М. Достоевскому хранится: ОР РГБ. Ф. 93.II.2.72. См. публикацию письма на сайте www.philolog.ru (http://philolog.petrsu.ru/fmdost/letters/ geibai/otgejbovich25031860.pdf).

11 Подробнее см.: [Заваркина, 2019].

12 См. также: Д30; 28, 105-106. Оригинал письма хранится в РО ИРЛИ. Ф. 407. № 1. С. 1.

13 См.: Михневичъ В. О. Петербургъ весь на ладони, съ планомъ Петербурга, его панорамой съ птичьяго полета, 22 картинками и съ прибавленіемъ календаря. СПб., 1874. С. 354. См. также: Всеобщая адресная книга С.-Петербурга, съ Васильевскимъ островомъ, Петербургскою и Выборгскою сторонами и Охтою: въ 5-ти отдъленіяхъ. С.-Петербургъ, 1867-68. С. 488.

14 Сборникъ Императорскаго Русскаго Историческаго Общества. СПб, 1888. Т. 62. С. 363.

15 Адресъ-календарь, или Общій штатъ Россійской имперіи на 1847 годъ. СПб., 1847. С. 66.

16 См. публикацию письма на сайте: www.philolog.ru (http://philolog.petrsu.ru/fmdost/letters/ gerih/otgerih07031865.htm).

17 В ЛН: «покорился» [ЛН, т. 83: 284].

18 В ЛН: «приобретенные» [ЛН, т. 83: 284].

19 Далее в ЛН до слов: «Другое дъло - Пруссія...» не расшифровано [ЛН, т. 83: 284].

20 Слово «земной» отсутствует в Д30 (см.: Д30; 20: 203).

21 Слово «міростяжателя» отсутствует в Д30 (см.: Д30; 20: 203).

22 Предложения: «Франиія съ ней Австрія всп не едины. Это націи... Цивилизованные націи<之 >» отсутствуют в ЛН и Д30 [ЛН, т. 83: 284], (Д30; 20: 203).

23 В ЛН и Д30 не прочитаны предложения: «Новая нація, - сильная циивилизація. Нюмиьь же должны сдюлать [отказб оть] новую изиилизацію. Стало-быть все дюло есть въ невпріи да и нпмиевъ мало для Австріи» [ЛН, т. 83: 284], (Д30; 20: 203).

24 На самом деле: «Записка...».

\section{СПИСОК ЛИТЕРАТУРЫ}

1. Алексеева Л. В. Проблемы атрибуции в исследованиях о Ф. М. Достоевском (обзор предложенных решений) // Неизвестный Достоевский. - 2015. - № 4. - С. 3-10 [Электронный ресурc]. - URL: http://unknown-dostoevsky.ru/journal/liter.php?id=2501 (01.07.2019). DOI: 10.15393/j10.art.2015.2501 
2. Белов С. В. Ф. М. Достоевский и его окружение: энциклопедический словарь: в 2 т. СПб.: Алетейя, 2001. - Т. 1. - 573 с.; Т. 2. - 544 с.

3. [Брокгауз Ф. А., Ефрон И. А.] Энциклопедический словарь: в 86 т. / изд. Ф. А. Брокгауз, И. А. Ефрон. - СПб.: Семеновская Типолитография (И. А. Ефрона), 1890-1903.

4. Гринченко Н. А., Патрушева Н. Г., Фут И. П. Цензоры Санкт-Петербурга: (1804-1917) // Новое литературное обозрение. - 2004. - № 69. - С. 364-394.

5. Достоевский в воспоминаниях современников: в 2 т. - М.: Худож. лит., 1990. - Т. 1. $623 \mathrm{c}$.

6. Достоевский Ф. М. Полн. собр. соч.: в 30 т. - Л.: Наука, 1972-1990.

7. Достоевский Ф. М. Полн. собр. соч.: канонические тексты / под ред. проф. В. Н. Захарова. - Петрозаводск: Изд-во ПетрГУ, 1995- (продолжающееся издание).

8. Достоевский Ф. М. Полн. собр. художественных произведений / под ред. Б. Томашевского и К. Халабаева. - М.; Л.: Госиздат, 1930. - Т. 13: Статьи. - 650 с.

9. Достоевский: сочинения, письма, документы: словарь-справочник / сост. и науч. ред. Г. К. Щенников, Б. Н. Тихомиров. - СПб.: Пушкинский Дом, 2008. - 470 с.

10. Заваркина М. В. Проблемы хронологической атрибуции «первой» записной книжки Ф. М. Достоевского // Неизвестный Достоевский. - 2018. - № 4. - С. 70-93 [Электронный ресурс]. - URL: http://unknown-dostoevsky.ru/files/redaktor_pdf/1545741405.pdf (01.07.2019). DOI: 10.15393/j10.art.2018.3789

11. Заваркина М. В. Проблемы хронологической атрибуции «второй» записной книжки Ф. М. Достоевского // Неизвестный Достоевский. - 2019. - № 2. - С. 5-39 [Электронный ресурс]. - URL: http://unknown-dostoevsky.ru/files/redaktor_pdf/1562145716.pdf (01.07.2019). DOI: 10.15393/j10.art.2019.4081

12. Захаров В. Н. Идеи «Времени», дела «Эпохи» // Достоевский Ф. М. Полн. собр. соч.: канонические тексты / под ред. проф. В. Н. Захарова. - Петрозаводск: Изд-во ПетрГУ, 2004. - T. V. - C. 697-712.

13. Захаров В. Н. Кодекс Достоевского. Журнализм как творческая идея писателя // Достоевский и журнализм / под ред. В. Захарова, К. Степаняна, Б. Тихомирова. - СПб.: Дмитрий Буланин, 2013. - C. 17-26. (Dostoevsky monographs; вып. 4) (a)

14. Захаров В. Н. Неопубликованный автограф Достоевского: Ф. М. Достоевский и С. П. Колошин // Ученые записки Петрозаводского государственного университета. Сер.: Общественные и гуманитарные науки. — 2013. - № 7 (136). - Т. 2. - С. 58-61. (b)

15. Каплин А. Д. Предисловие // Беляев И. Д. Лекции по истории русского законодательства. - М.: Институт русской цивилизации, 2011. - С. 5-30.

16. Летопись жизни и творчества Ф. М. Достоевского. 1821-1881: в 3 т. - СПб.: Академический проект, 1993. - Т. 1: 1821-1864. - 544 с.; 1994. - Т. 2: 1865-1874. — 592 с.

17. Маскевич Е. Д., Тихомиров Б. Н. Из юных лет Михаила и Федора Достоевских (Новые архивные материалы 1837-1839 гг.) // Неизвестный Достоевский. - 2019. - № 2. C. 56-93 [Электронный ресурс]. — URL: http://unknown-dostoevsky.ru/files/redaktor_ pdf/1562749532.pdf (10.07.2019). DOI: 10.15393/j10.art.2019.3981

18. Мезьер А. В. Словарь русских цензоров: материалы к библиографии по истории русской цензуры. - М., 2000. - 142 [2] с.

19. Неизданный Достоевский. Записные книжки и тетради 1860-1881 гг. - М.: Наука, 1971. - 727 с. (Литературное наследство; т. 83).

20. Нечаева В. С. Журнал М. М. и Ф. М. Достоевских «Время» (1861-1863). - М.: Наука, 1972. -317 c. 
21. Нечаева В. С. Журнал М. М. и Ф. М. Достоевских «Эпоха» (1864-1865). - М.: Наука, 1975. $-303 \mathrm{c}$.

22. [Орнатская Т. И.] Рукою Достоевского / публ. Т. И. Орнатской // Достоевский. Материалы и исследования. - Л.: Наука, 1985. - Вып. 6. - С. 3-31.

23. Тарасова Н. А., Заваркина М. В., Панюкова Т. В. Графические особенности рукописей Достоевского: материалы для информационной базы данных // Неизвестный Достоевский. - 2018. - № 4. - С. 17-69 [Электронный ресурс]. - URL: http://unknowndostoevsky.ru/files/redaktor_pdf/1545737853.pdf. (05.07.2019). DOI: 10.15393/j10.art.2018.3788

24. Тихомиров Б. Н. Петербургские адреса и адресаты Достоевского (К проблеме краеведческого комментирования адресных записей писателя). Статья вторая // Неизвестный Достоевский. — 2018. — № 3. - С. 56-105 [Электронный pecypc]. — URL: http:// unknown-dostoevsky.ru/files/redaktor_pdf/1541001296.pdf (05.07.2019). DOI: 10.15393/j10. art.2018.3701

25. Туниманов В. А. Комментарии: Ф. М. Достоевский. Ряд статей о русской литературе. Книжность и грамотность // Достоевский Ф. М. Собр. соч.: в 15 т. - СПб.: Наука, 1993. - Т. 11. - С. 445-467.

26. Хроника рода Достоевского / под ред. И. Л. Волгина. - М.: Фонд Достоевского, 2012. 1232 с., илл.

Marina V. Zavarkina

Petrozavodsk State University

(Petrozavodsk, Russian Federation)

dostoyevsky@mail.ru

\section{Editorial Notes in the Notebooks of F. M. Dostoevsky in 1860-1865}

Acknowledgements. The reported study was funded by RFBR, project number 18-012-90016 Dostoevsky.

Abstract. The article analyzes records from the notebooks of F. M. Dostoevsky (RGB. F. 93.I.2.6, 93.I.2.7, 93.I.2.8) that the writer kept in 1860-1865 in parallel with the publication of the journals "Time" and "Epoch". Some of these records still remain undeciphered or were deciphered inaccurately, others have no comments. The article presents the results of attempts to read the individual records, taking into account the characteristics of the writer's handwriting, and also it offers comments that complement the comments to the first publication of his books in the 83d volume of "The Literary heritage" (1971) and later in the 20th volume of the Complete works of F. M. Dostoevsky compiled in 30 volumes (1980). The Identification and study of these records as a part of the notebooks and diaries Dostoevsky will allow us to cover more in detail the busy life of the writer during the period of his editorial activity in the magazines "Time" and "Epoch", as well as to understand the type of his work as a writer and journalist. The topic of the article needs further study and is of polemical character.

Keywords: F. M. Dostoevsky, "Time”, "Epoch", manuscripts, attribution, notebooks and workbooks

About the author: Zavarkina Marina V. - PhD of Philology, Specialist, WEB-laboratory of Institute of Philology, Petrozavodsk State University (pr. Lenina 33, Petrozavodsk, Republic of Karelia, 185910, Russian Federation)

Received: 15.07.2019

Date of publication: 14.09.2019

For citation: Zavarkina M. V. Editorial Notes in the Notebooks of F. M. Dostoevsky in 1860-1865. In: Neizvestnyy Dostoevskiy [The Unknown Dostoevsky], 2019, no. 3, pp. 67-95. DOI: 10.15393/ j10.art.2019.4141 (In Russ.) 


\section{REFERENCES}

1. Alekseeva L. V. Attribution Problems in the Research Works About F. M. Dostoevsky (A Review of the Proposed Approaches). In: Neizvestnyy Dostoevskiy [The Unknown Dostoevsky], 2015, no. 4, pp. 3-10. Available at: http://unknown-dostoevsky.ru/files/redaktor_pdf/1453708925. pdf (accessed on July 1, 2019). (In Russ.)

2. Belov S. V. F. M. Dostoevskiy i ego okruzhenie. Entsiklopedicheskiy slovar': v 2 tomakh [F. M. Dostoevsky and His Ambience. Encyclopedic Dictionary: in 2 Vols]. St. Petersburg, Aleteyya Publ., 2001. (In Russ.)

3. Brockhaus F. A., Efron I. A. Entsiklopedicheskiy slovar': $v 86$ tomakh [Encyclopedic Dictionary: in 86 Vols]. St. Petersburg, Semenovskaya Tipolitografiya (I. A. Efrona) Publ., 1890-1903. (In Russ.)

4. Grinchenko N. A., Patrusheva N. G., Fut I. P. Censors of St. Petersburg: (1804-1917). In: Novoe literaturnoe obozrenie [New Literary Observer], 2004, no. 69, pp. 364-394. (In Russ.)

5. F. M. Dostoevskiy v vospominaniyakh sovremennikov: $v 2$ tomakh [F. M. Dostoevsky in Memoirs of His Contemporaries: in 2 Vols]. Moscow, Khudozhestvennaya literatura Publ., 1990, vol. 1. 623 p. (In Russ.)

6. Dostoevskiy F. M. Polnoe sobranie sochineniy: $v 30$ tomakh [The Complete Works: in 30 Vols]. Leningrad, Nauka Publ., 1972-1990. (In Russ.)

7. Dostoevskiy F. M. Polnoe sobranie sochineniy: kanonicheskie teksty [The Complete Works: Canonical Texts]. Petrozavodsk, PetrSU Publ., 1995- (the ongoing ed.) (In Russ.)

8. Dostoevskiy F. M. Polnoe sobranie khudozhestvennykh proizvedeniy [Dostoevsky F. M. The Complete Works of Fiction]. Moscow, Leningrad, Gosizdat Publ., 1930, vol. 13: Articles. 650 p. (In Russ.)

9. Dostoevskiy: sochineniya, pis'ma, dokumenty: slovar'-spravochnik [Dostoevsky: Works, Letters and Documents: Dictionary and Reference Book]. St. Petersburg, Pushkinskiy Dom Publ., 2008. 470 p. (In Russ.)

10. Zavarkina M. V. The Problems of the Chronological Attribution of "the First" Notebook of F. M. Dostoevsky. In: Neizvestnyy Dostoevskiy [The Unknown Dostoevsky], 2018, no. 4, pp. 70-93. Available at: http://unknown-dostoevsky.ru/files/redaktor_pdf/1545741405.pdf (accessed on July 1, 2019). (In Russ.)

11. Zavarkina M. V. The Problems of the Chronological Attribution of "the Second" Notebook of F. M. Dostoevsky. In: Neizvestnyy Dostoevskiy [The Unknown Dostoevsky], 2019, no. 2, pp. 5-39. Available at: http://unknown-dostoevsky.ru/files/redaktor_pdf/1562145716.pdf (accessed on July 1, 2019). (In Russ.)

12. Zakharov V. N. The Ideas of "Vremya", the Deeds of "Epokha". In: Polnoe sobranie sochineniy: kanonicheskie teksty [The Complete Works: Canonical Texts]. Petrozavodsk, PetrSU Publ., 2004, vol. 5. (In Russ.)

13. Zakharov V. N. The Dostoevsky's Code. Journalism as a Creative Idea of the Writer. In: Dostoevskiy i Zhurnalizm [Dostoevsky and Journalism]. St. Petersburg, Dmitriy Bulanin Publ., 2013, pp. 17-26. (Dostoevsky monographs; vol. 4). (In Russ.) (a)

14. Zakharov V. N. An Unpublished Autograph of Dostoevsky: F. M. Dostoevsky and S. P. Koloshin. In: Uchenyye zapiski Petrozavodskogo gosudarstvennogo universiteta [Scientific Notes of Petrozavodsk State University. Ser.: Social Sciences and Humanities]. Petrozavodsk, PetrSU Publ., 2013, November, no 7 (136), vol. 2, pp. 58-61. (In Russ.) (b) 
15. Kaplin A. D. Preface. In: Belyaev I. D. Lektsii po istorii russkogo zakonodatel'stva [Belyaev I. D. Lectures on the History of Russian Legislation]. Moscow, Institute of Russian civilization Publ., 2011, pp. 5-30. (In Russ.)

16. Letopis' zhizni i tvorchestva F. M. Dostoevskogo: v 3 tomakh [The Chronicle of Dostoevsky's Life and Works: in 3 Vols]. St. Petersburg, Akademicheskiy proekt Publ., 1993, vol. 1. 543 p.; 1994, vol. 2. 592 p. (In Russ.)

17. Maskevich E. D., Tikhomirov B. N. Some Facts from the Young Years of Mikhail and Fedor Dostoevsky (New Archival Materials of 1837-1839). In: Neizvestnyy Dostoevskiy [The Unknown Dostoevsky], 2019, no. 2, pp. 56-93. Available at: http://unknown-dostoevsky.ru/files/ redaktor_pdf/1562749532.pdf (accessed on July 10, 2019). (In Russ.)

18. Mezyer A. V. Slovar' russkikh tsenzorov. Materialy $k$ bibliografii po istorii russkoy tsenzury [Russian Censors' Dictionary: Materials for the Bibliography on the History of Russian Censorship]. Moscow, 2000. 142 p. (In Russ.)

19. Neizdannyy Dostoevskiy: Zapisnye knizhki i tetradi 1860-1881 godov [The Unpublished Dostoevsky: Notebooks and Workbooks of 1860-1881]. Moscow, Nauka Publ., 1971. 727 p. (Ser. "The Literary Heritage"; vol. 83). (In Russ.)

20. Nechaeva V. S. Zhurnal M. M. i F. M. Dostoevskikh «Vremya» (1861-1863) [The Journal of Mikhail and Fedor Dostoevsky "Vremya" (1861-1863)]. Moscow, Nauka Publ., 1972. 317 p. (In Russ.)

21. Nechaeva V. S. Zhurnal M. M. i F. M. Dostoevskikh «Epokha» (1864-1865) [The Journal of Mikhail and Fedor Dostoevsky "Epokha" (1864-1865)]. Moscow, Nauka Publ., 1975. 303 p. (In Russ.)

22. Ornatskaya T. I. Dostoevsky's Handwriting. In: Dostoevskiy. Materialy i issledovaniya [Dostoevsky. Materials and Researches]. Leningrad, Nauka Publ., 1985, vol. 6, pp. 3-31. (In Russ.)

Tarasova N. A., Zavarkina M. V., Panyukova T. V. The Graphic Peculiarities of Dostoevsky's Manuscripts: Materials for Information Database. In: Neizvestnyy Dostoevskiy [The Unknown Dostoevsky], 2018, no. 4, pp. 17-69. Available at: http://unknown-dostoevsky.ru/files/ redaktor_pdf/1545737853.pdf (accessed on July 5, 2019). (In Russ.)

23. Tikhomirov B. N. Dostoevsky's Addresses and Addressees in St. Petersburg (More on the Problem of Regional Comments on the Address Records of the Writer). Article Two. In: Neizvestnyy Dostoevskiy [The Unknown Dostoevsky], 2018, no. 3, pp. 56-105. Available at: http://unknown-dostoevsky.ru/files/redaktor_pdf/1541001296.pdf (accessed on July 5, 2019). (In Russ.)

24. Tunimanov V. A. Comments: F. M. Dostoevsky. A Number of Articles About Russian Literature. Books and Literacy. In: Sobranie sochineniy: $v 15$ tomakh [Collected Works: in 15 Vols]. St. Petersburg, Nauka Publ., 1993, vol. 11, pp. 445-467. (In Russ.)

25. Khronika roda Dostoevskogo [The Chronicle of the Dostoevsky Dynasty]. Moscow, Fond Dostoevskogo Publ., 2012. 1232 p. (In Russ.) 